\title{
Translational Considerations to Improve Response and Overcome Therapy Resistance in Immunotherapy for Hepatocellular Carcinoma
}

\author{
Sophia Heinrich ${ }^{1,2, \dagger}{ }^{\text {, Darko Castven }}{ }^{2,3, \dagger}$, Peter R. Galle ${ }^{4, *}$ and Jens U. Marquardt ${ }^{2,3, *}$ \\ 1 Laboratory of Human Carcinogenesis, Liver Carcinogenesis Section, Center for Cancer Research, National \\ Cancer Institute, National Institutes of Health, Bethesda, MD 20892, USA; sophia.franck@nih.gov \\ 2 Department of Medicine I, Lichtenberg Research Group for Molecular Hepatocarcinogenesis, \\ University Medical Center, 55131 Mainz, Germany; darko.castven@uksh.de \\ 3 Lichtenberg Research Group for Molecular Hepatocarcinogenesis, Department of Medicine I, \\ University Medical Center Schleswig Holstein, 23538 Luebeck, Germany \\ 4 Department of Medicine I, University Medical Center, 55131 Mainz, Germany \\ * Correspondence: peter.galle@unimedizin-mainz.de (P.R.G.); Jens.Marquardt@uksh.de (J.U.M.); \\ Tel.: +49-06131-17-7275 (P.R.G.); +49-0451-500-44101 (J.U.M.); Fax: +49-06131-17-5595 (P.R.G.); \\ +49-0451-500-44104 (J.U.M.) \\ + These authors contributed equally to this work.
}

Received: 4 August 2020; Accepted: 31 August 2020; Published: 3 September 2020

Simple Summary: Immunotherapeutic approaches became a promising treatment option and an intensive field of research in liver cancer. Despite promising results in preclinical studies, only moderate response rates have been reported in phase III clinical trials and predictive biomarkers are still missing. Therefore, translational considerations are important to overcome resistance to immunotherapy. This article reviews potential predictors for response to immunotherapy in hepatocellular carcinoma (HCC) as well as potential mechanisms for therapy resistance. Further, we will discuss translational considerations to overcome therapy resistance in HCC and improve overall response rates.

\begin{abstract}
Over the last decade, progress in systemic therapies significantly improved the outcome of primary liver cancer. More recently, precision oncological and immunotherapeutic approaches became the focus of intense scientific and clinical research. Herein, preclinical studies showed promising results with high response rates and improvement of overall survival. However, results of phase III clinical trials revealed that only a subfraction of hepatocellular carcinoma (HCC) patients respond to therapy and display only moderate objective response rates. Further, predictive molecular characteristics are largely missing. In consequence, suitable trial design has emerged as a crucial factor for the success of a novel compound. In addition, increasing knowledge from translational studies indicate the importance of targeting the tumor immune environment to overcome resistance to immunotherapy. Thus, combination of different immunotherapies with other treatment modalities including antibodies, tyrosine kinase inhibitors, or local therapies is highly promising. However, the mechanisms of failure to respond to immunotherapy in liver cancer are still not fully understood and the modulation of the immune system and cellular tumor composition is particularly relevant in this context. Altogether, it is increasingly clear that tailoring of immunotherapy and individualized approaches are required to improve efficacy and patient outcome in liver cancer. This review provides an overview of the current knowledge as well as translational considerations to overcome therapy resistance in immunotherapy of primary liver cancer.
\end{abstract}

Keywords: hepatocellular carcinoma; immunotherapy; translational approaches; combination therapies; therapy resistance 


\section{Introduction}

Primary liver cancer, in particular hepatocellular carcinoma (HCC) ranks among the most common malignancies worldwide with a rising incidence in the Western world [1-4]. Between $80-90 \%$ of HCC cases develop in an inflammation-associated milieu [5], i.e., on the background of a pre-existing chronic liver disease and, most commonly, an advanced fibrosis or cirrhosis. Due to demographic changes in the distribution of diabetes mellitus type II and obesity, non-alcoholic fatty liver disease, or steatohepatitis (non-alcoholic fatty liver disease (NAFLD)/non-alcoholic steatohepatitis (NASH)) show a sharp increase in HCC numbers [6] and are considered as metabolic predispositions to liver cancer $[7,8]$. Numerous immune suppressor mechanisms that involve different immune cell types lead to immune evasion of the tumor and have been shown to contribute to HCC initiation and progression $[9,10]$.

Despite well known risk factors, i.e., chronic viral hepatitis, alcohol consumption, and metabolic syndrome, the majority of HCC patients are diagnosed in late, non-resectable, and non-curative stages of the disease, when a considerable phenotypic and molecular heterogeneity renders HCC highly resistant to conventional chemotherapy and/or irradiation [11]. Until 2016, only limited systemic treatment options were available in advanced stages of HCC, namely sorafenib and regorafenib, tyrosine kinase inhibitors (TKI) [12-14]. Since then, only Lenvatinib (first-line), regorafenib, cabozantinib, all TKIs, and ramucirumab (second-line), a monoclonal antibody against VEGFR, have shown efficacy in phase III clinical trials [13,15-17]. Despite the approval of new and targeted therapy, patients' prognosis remained limited to 12-13 months in first-line and 9-11 months in second-line therapy, and besides alpha-fetoprotein (AFP), there is no biomarker available for patient stratification [18].

Given the inflammatory background of HCC, the hepatic tumor microenvironment (TME) plays a pivotal role in tumor initiation, modulation of tumor invasiveness, metastatic spread as well as tumor suppression and immune surveillance of cancer cells [19]. Therefore, modern therapeutic approaches that focus on modulation of the TME are particularly promising.

The liver is an immune tolerant organ due to its prominent role in protection against inappropriate immune responses. The inflammatory stimuli emerge as a consequence to exposition with major inflammatory processes mediated by a large antigenic load from the gastrointestinal tract trough blood from the portal vein [20]. In addition, the setting of a chronic liver inflammation or cirrhosis further reinforces the hepatic immune tolerance [21]. On a single cell level, it has been demonstrated that HCCs show a higher abundance of regulatory $\mathrm{T}$ cells $\left(\mathrm{T}_{\text {regs }}\right)$ as well as their local clonal expansion within the tumor. Furthermore, a higher abundance of exhausted CD8 T cells is present in the tumor tissue [22]. This has a significant influence on tumor surveillance. Decreased number of tumor attacking immune cells such as T effector cells and more tumor supporting cells, e.g., MDSCs and $\mathrm{T}_{\text {regs }}$ lead to a disruption of the cellular composition during chronic liver diseases and is associated with patient outcome [23-28]. During hepatocarcinogenesis, several immunosuppressive effects have been detected that are associated with patient survival. Immune cell composition leading to anti-tumor immunity or tolerance is crucial for tumor growth or cell death. $\mathrm{T}_{\text {regs }}$ as well as myeloid derived suppressor cells (MDSC) accumulate in the liver and suppress antitumor immunity in HCC [9,29]. Macrophages, in the liver called Kupffer cells, suppress early HCC development; however, undergo a switch from M1 to M2 during tumor progression, which leads to a suppression of the adaptive immune system and support of the tumor [10,30-33]. Tumor associated macrophages (TAM) represent the predominant component of the innate immune system and promote tumor proliferation, angiogenesis and invasion [34,35] Furthermore, parenchymal cells such as endothelial cells, hepatic stellate cells (HSC), and hepatocytes influence effector functions of infiltrating lymphocytes [21]. This leads to an intratumoral loss of cytotoxic T cells, which is associated with tumor progression $[21,35,36]$. Natural killer (NK) cell, important players of innate immunity in the liver, show an impaired function in HCCs $[29,37]$. This dysfunctional and imbalanced immune system is a hallmark of cancer progression in HCC and is associated with patient prognosis. [38,39] 
After the approval of immune checkpoint inhibitors (ICI) in melanoma and non-small cell lung cancer (NSCLC), immunotherapies have raised significant interest in other solid tumors including HCC. In 2017 and 2018, the FDA granted accelerated approval for the first immunotherapy agents, nivolumab and pembrolizumab or the combination of nivolumab and ipilimumab, for patients with advanced HCC after progression under sorafenib after promising results from phase II clinical trials [40-42]. Other checkpoint inhibitors are currently being investigated in clinical trials as single agents as well as in combination therapies [42-45]. A detailed list of currently approved immunotherapeutic agents can be found in Table 1. Nevertheless, immunotherapy in liver cancer has been challenging. Objective response rates are still low. Given the fact that only some patients respond to therapy, the various degrees of side effects such as autoimmune reactions need to be taken into account $[40,46,47]$. Thus, predictive biomarkers are urgently needed. Furthermore, there are no long-term data for those patients responding to therapy and even though there are some studies addressing a neoadjuvant treatment option, we do not have any strong data in curative settings yet. However, first results from combination therapies show a significant improvement in all clinical endpoints including overall survival and quality of life, which raises optimism for the future of this approach in primary liver cancer [48]. Even scenarios in adjuvant or neoadjuvant use are now under current discussion $[49,50]$, but our overall understanding of the treatment response remains limited.

Table 1. Currently approved immunotherapy in hepatocellular carcinoma (HCC)

\begin{tabular}{ccc}
\hline Target Molecule & Drug Name & Company \\
\hline PD-1 & Nivolumab & Bristol Meyer Squibb \\
\hline PD-1 & Pembrolizumab & Merck \\
\hline PD-L1 & Atezolizumab & Roche \\
\hline CTLA-4 & (in combination with bevacizumab) & Bristol Meyer Squibb/Medarex \\
\hline $\begin{array}{l}\text { Abbreviations: PD-1 (programmed cell death protein 1), PD-L1 (programmed cell death ligand 1), CTLA-4 (cytotoxic } \\
\text { T-lymphcyte-associatet protein 4). }\end{array}$
\end{tabular}

Given the success of immunotherapy in several tumor entities, we here review the potential predictors for response to immunotherapy in HCC. In addition, we are addressing potential mechanisms for therapy resistance. Finally, we discuss translational considerations to overcome therapy resistance in HCC.

\section{General Strategies for Immunomodulatory Treatments in Primary Liver Cancer}

There are different strategies to induce antitumor immune response that are currently under investigation in primary liver cancer involving both innate and adaptive immune systems. Specifically, targeting of checkpoint molecules as well as the interaction of $\mathrm{T}$ cells and antigen-presenting cells (APCs) have been of interest in recent years [51]. Neoantigens expressed on the tumor itself can also be used as targets for immunotherapy [52]. Local therapies and oncolytic viruses can promote neoantigen release even more, thereby further enhancing the antitumor immune response [53,54]. In addition, detailed information on tumor neoantigens can be explored to develop anti-tumor vaccines and autologous $\mathrm{T}$ cells can be manipulated and/or stimulated ex vivo before retransfer, e.g., chimeric antigen receptor (CAR) T cells or cytokine-induced killer cells (Figure 1) [55,56]. 


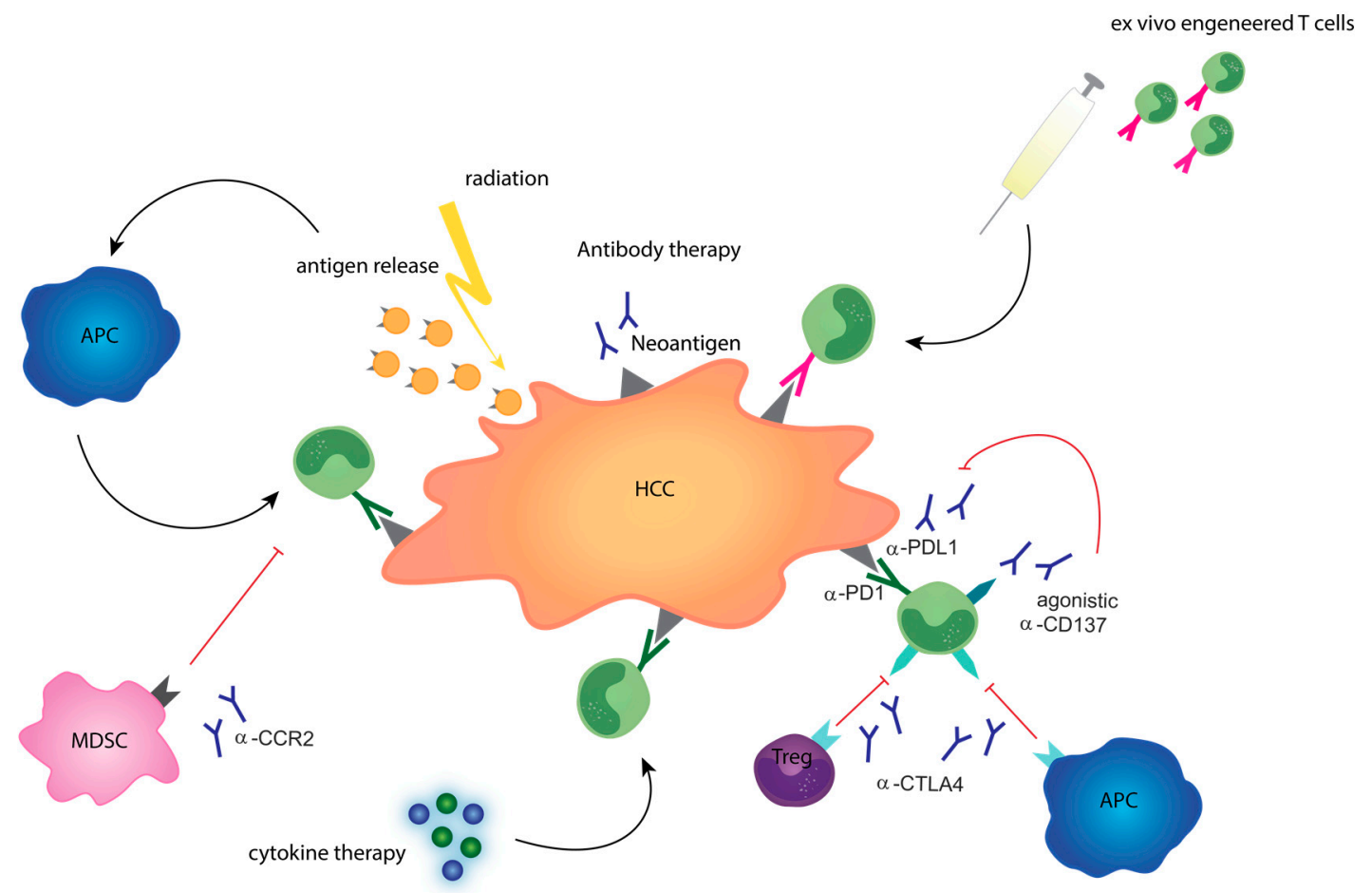

Figure 1. Overview of therapeutic approaches in immunotherapy. Targeted antibody therapy can block inhibitory signals, e.g., CTLA-4 or PD-1 and "unleash" anti-tumor immunity or block immunosuppressive mechanisms of the adaptive as well as the innate immune system. Besides a direct anti tumoral effect, irradiation leads to an antigen release that promotes antigen presentation by APCs and enhances anti-tumoral $\mathrm{T}$ cell response. Cytokine therapy is an option to enhance a general $\mathrm{T}$ cell response in the tumor. Ex-vivo engineered T cells or antibodies against tumor specific neoantigens induce a targeted anti-tumor response. Abbreviations: Myeloid derived suppressor cell (MDSC), antigen presenting cell (APC), regulatory T cell (Treg), cytotoxic T lymphocyte antigen 4 (CTLA4), programmed death protein (PD1), programmed death ligand 1 (PDL1).

However, it is well known that immune escape and evasion of immune-mediated cytotoxicity are among the hallmarks of cancers and are often mediated by induction of an immunosuppressive microenvironment $[57,58]$. To overcome escape from immunosurveillance by cancer cells, therapeutic approaches focus on boosting antitumor response either by activation of cytotoxic immune cells or elimination of immune-suppressing cells. Furthermore, tumors also evade from the immune system by upregulation of programmed cell death ligand 1 (PD-L1) on cancer cells. Tumor immune cell interactions are based on two phases of $\mathrm{T}$ cell activation: an early priming phase in the lymph node and an effector phase in the tumor tissue. Involved in this process are APCs, that bind cancer antigens, migrate to the lymph node, and activate immature $\mathrm{T}$ cells. Activation of $\mathrm{T}$ cells in the priming phase can be blocked by upregulation of the checkpoint molecule cytotoxic T lymphocyte antigen 4 (CTLA-4) on T cells. CTLA-4 is also highly expressed on $\mathrm{T}_{\text {regs }}$ that inhibit antigen presentation on dendritic cells (DC). This is a cycle, that leads to less cytotoxic, more exhausted T cells and, thus, impaired anti-tumor response. Activation of $\mathrm{T}$ cells in the effector phase can be blocked by programmed death protein 1 (PD-1)/ programmed death ligand 1(PD-L1) that is expressed in tumor cell interaction. Both "breaks" can be effectively released by anti-PD-1, anti PD-L1, or anti CTLA-4 therapy and enhance anti-tumor immune response (Figure 2) [40,43,59,60].

In HCC, immunotherapy is an intensively studied field encompassing all the above mentioned antibody-based, cell-based, and vaccine-based treatment options [61]. In addition, the combination of different therapy regimes may provide a significant benefit (Figure 1) [43]. 


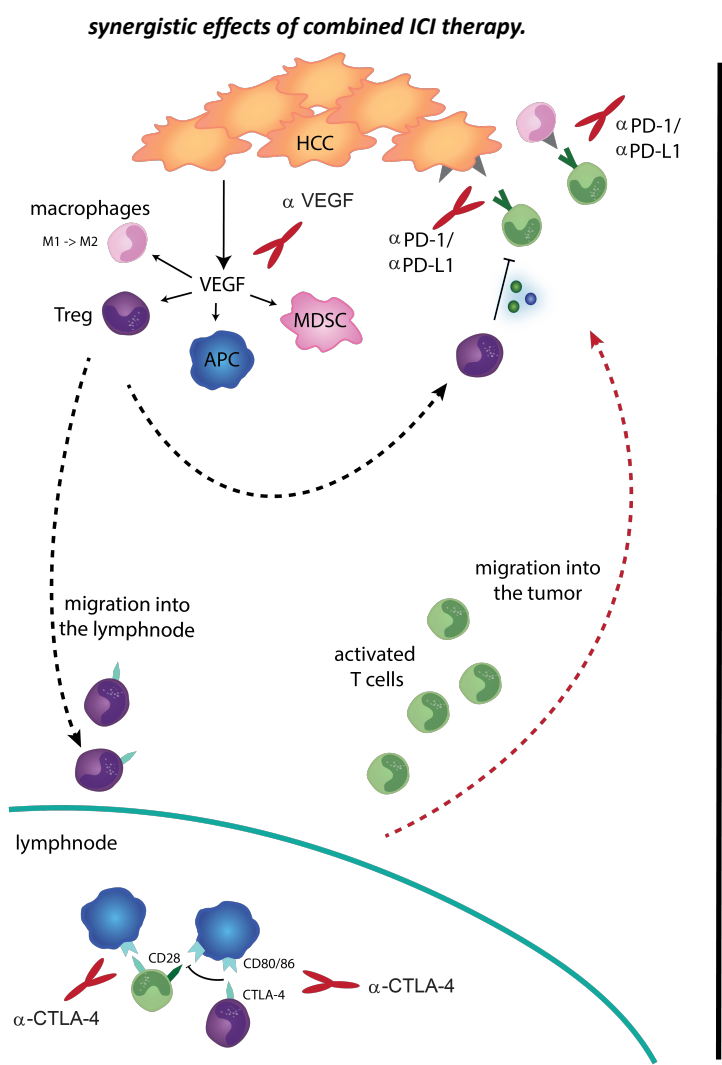

potential molecular targets provide synergistic effects for ICI.

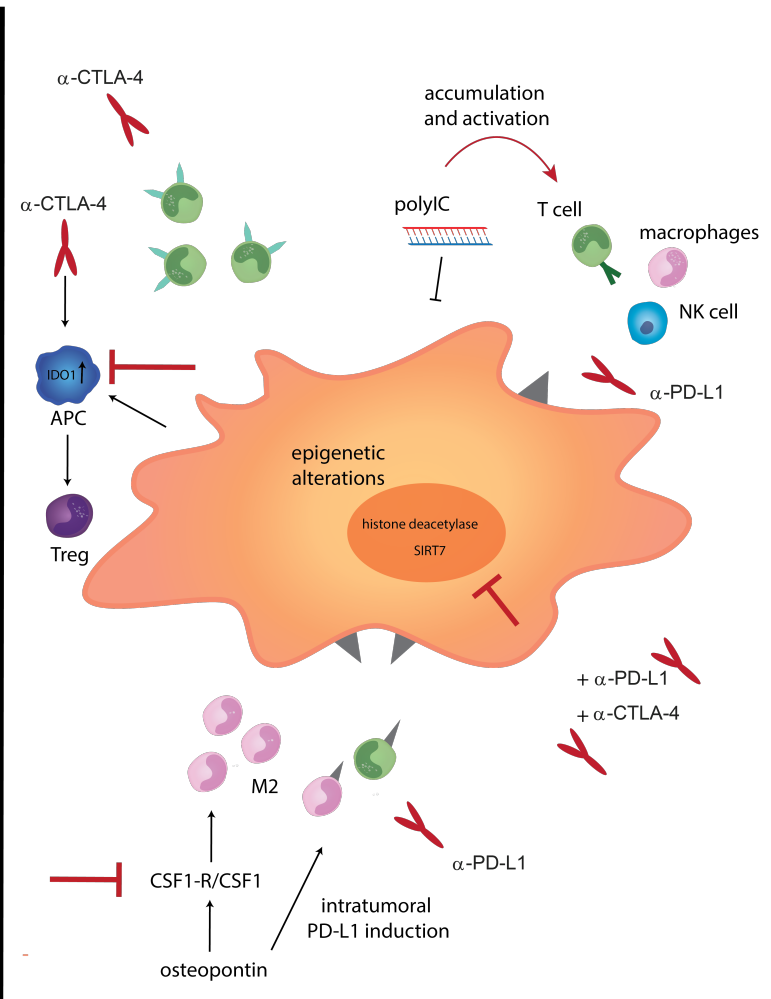

Figure 2. Translational consideration to overcome therapy resistance. Therapeutic approaches for sensitization to immunotherapy. Left panel: Anti-CTLA-4 or anti-angiogenic therapy increases recruitment and migration of activated T cells into the tumor. Anti-PD-1/anti PD-L1 therapy enhances cytolytic activity of T cells. Right panel: Anti-CTLA-4 treatment induced IDO1 expression in dendritic cells (DC). Indoleamine 2,3-dioxygenase 1 (IDO1) leads to activation of $\mathrm{T}_{\text {regs }}$ and causes resistance to anti-CTLA-4 therapy, while blocking of IDO could interrupt this mechanism of resistance. PolyIC inhibits tumor growth and leads to an accumulation and activation of immune cell subsets, whereas anti-PD-L1 therapy could provide synergistic effects. Osteopontin induces M2 migration into the tumor as well as PD-L1 induction. Targeted therapy of CSF1 in combination with anti-PD-L1 therapy might provide synergistic effects. Epigenetic regulations as synergistic effect for ICI therapy.

\section{Predictors for Response or Resistance to Current Immune-Modulatory Therapies}

Immunotherapy as a modern approach for cancer treatment has become a key topic in translational research over the last decade. After approval of the first PD-1/PD-L1 and CTLA-4 blocking antibodies for melanoma, checkpoint inhibitors are under intense investigation in many tumor entities. Unleashing of the immune system to attack the tumor seems to be an effective anti-tumor treatment. Many immunotherapies have been shown to be effective as monotherapies but also in combination with other immune-based and targeted approaches in preclinical and clinical studies [62-66]. However, despite good clinical efficacy in other tumor entities, response rates in HCC as well as cholangiocarcinoma are surprisingly low [40,67-70]. A common observation in HCC is the missing significance or lack of surrogate markers of response utilized in other entities. Thus, improved strategies to estimate therapy response would enable to stratify patients according to their clinical benefit and prevent unnecessary side effects caused by the therapy [40,70-73].

Mechanisms of resistance to immunotherapy are still not fully understood. Especially in the context of a possible pseudoprogression or even hyperprogression under immunotherapy, predictive biomarkers are urgently needed [74]. 


\subsection{Tumor Characteristics and Tumor Infiltrating Lymphocytes as Predictors for Response}

Multiple studies revealed potential molecular characteristics that are associated with immunotherapy response. However, up to now, no biomarker for HCC has been prospectively validated in authentic human patients. The most prominent biomarkers are PD-1 and PD-L1 expression on tumor tissue as well as on infiltrating immune cells.

Expression of PD-1/PD-L1 in HCC have been described in 17\% (PD-L1) and 27\% (PD-1) on immune and $10-20 \%$ (PD-L1) on tumor cells, using immunohistochemistry [40,41,75-77]. High PD-L1 expression in tumors itself is associated with more aggressive HCCs independent of immunotherapy $[76,78]$.

Several translational studies investigated numbers of immune cells and respective activation of checkpoint molecules as possible biomarkers for immunotherapy response in HCC. In other entities such as NSCLC, PD- $1^{\text {high }} \mathrm{T}$ cells showed a higher capacity for tumor recognition, recruit other immune cells, and are predictive for response and overall survival under PD-1 therapy, which demonstrates that a distinct $\mathrm{T}$ cell subtype is needed for response to PD-1/PD-L1 therapy [79]. In HCC patients, high PD-1 expression in tumor tissue is connected to an exhausted immune cell phenotype with impaired effector function of tumor infiltrating lymphocytes (TIL), which contributes to immune evasion [75,80-82]. A recent study further demonstrated that PD-1, LAG3 (lymphocyte activation gene 3), TIM3 (T cell membrane protein 3), and CTLA-4 positive TILs are exhausted and functionally compromised, thus, induce lower levels of effector cytokines. Conversely, this phenotype could be reversed back to an effector phenotype with ICI [82].

Using sequencing and TCR analysis, another study investigated the distribution of mutational and neoantigen burden in different tumor regions as a possible driver for immune cell heterogeneity. Analysis of peptide binding affinity of these neoantigens revealed a correlation of the higher ones with TIL heterogeneity. However, the region with the highest TIL heterogeneity showed the lowest putatively immunogenic neoepitopes, suggesting that the adaptive immune response has edited the tumor to be less immunogenic [83].

Another study stratified HCC patients into $\mathrm{CD} 8^{+} \mathrm{PD}-1^{\text {high }}$ and $\mathrm{CD} 8^{+} \mathrm{PD}-1^{\text {low }}$. A gene signature that effectively predicted anti-PD-1 therapy response in several tumor entities was significantly enriched in corresponding PD- ${ }^{\text {high }}$ expressers [75]. Furthermore, high frequencies of $\mathrm{CD} 14^{+} \mathrm{CD} 16^{-} \mathrm{HLA}-\mathrm{DR}{ }^{\text {high }}$ monocytes was shown to predict therapy response in melanoma patients [84]. This phenotype was also elevated in PD-1 ${ }^{\text {high }}$ expressers [75]. Both findings might provide an indirect surrogate of therapy response in PD-1 ${ }^{\text {high }}$ HCC patients. Consistently, the PD- $1^{\text {high }}$ HCCs also expressed markers such as LAG3 and TIM3 confirming the exhausted phenotype of the cells and delineating the rational of targeting these markers in liver cancer. In vitro experiments could further show that blocking of PD-1 increased IFN production and effectively enhanced the immune response. However, this effect was only present in PD-1 ${ }^{\text {high }}$ HCCs [75].

Recently, single cell sequencing approaches became affordable and promising tools for translational science. These investigations are ideal to dissecting immune cell populations in the context of the diseased hepatic microenvironment as well as immunotherapies. A recent single cell sequencing analysis demonstrated a complex composition of highly diverse T cell subpopulations in HCC tumors [22]. A subgroup expressing high levels of exhaustion markers such as CTLA4 and PDCD1 was identified that stratified patients according to the clinical outcome [22]. Furthermore, complex composition of immune cells could be revealed and shown to be spatially different between intratumoral regions, extra-tumoral regions, ascites, and the peripheral blood [85]. While modulation of this immune cell contexture could be highly promising in a therapeutic setting, the clinical use of cellular compositions as predictors for therapy response needs to be evaluated.

Only one single cell study focused on the malignant cells in HCC so far. Analysis of the tumor and the TME identified VEGFA ${ }^{\text {high }}$ tumors that drive the TME reprogramming [86]. Consequently, further single cell analysis of T cells revealed different transcriptomic profiles in VEGFA ${ }^{\text {high }}$ tumors. These observations imply that a combination of vascular endothelial growth factor (VEGF) therapy and immunotherapy might help to overcome some non-response mechanisms. 
Overall, results of these preclinical studies suggest that it is probably not enough to screen for widely expressed markers in the tissue and underline the importance of detailed characterization of the cellular compositions to shed light into cellular interactions to reveal context-dependent response mechanisms to immunotherapy.

For objective comparison of PD-L1 expression in clinical trials, mainly two different scoring systems have been established $[87,88]$. The tumor proportion score (TPS) calculates the percentage of PD-L1 tumor cells of all viable tumor cells, whereas the combined positive score (CPS) calculates the percentage of all PD-L1 positive cells (tumor cells, macrophages, lymphocytes) divided by all viable tumor cells $[87,88]$. PD-1/PD-L1 expression in tissue is associated with therapy response in melanoma, NSCLC, renal cancer and gastric cancer in large clinical trials [59,87,89-91].

Despite the promising results from the above-mentioned translational studies, explorative investigations performed on patients in clinical trials have failed to identify robust predictive markers that clearly identify patients likely to benefit from immunotherapy in HCC up to now.

Clinical trials for HCC using ICI included both of the mentioned scores to predict response. The CHECKMATE-40 trial, investigating the anti-PD-1 antibody Nivolumab as a second line therapy in HCC reported response rates regardless of PD-L1 expression rates. PD-L1 expression was calculated using the TPS score (overall response rate (ORR) $26 \%$ in patients with PD-L1 expression $>1 \%$ and ORR $19 \%$ of patients with PD-L1 expression $<1 \%$,). However, PD-L1 expression $>1 \%$ could only be detected in $20 \%$ of the patient population. The lack of robust association indicates that PD-L1 expression on tumor cells cannot be used as a single binary marker for therapy decisions [40]. The phase II clinical trial KEYNOTE-224 used the anti-PD-1 antibody pembrolizumab after progression under sorafenib. Response to therapy was assessed using TPS as well as CPS score [41]. Only CPS score showed significant association with response to therapy. The proportion of CPS score positive patients in the KEYNOTE cohort has been reported as $42 \%$ [41]. Although the follow-up phase III study KEYNOTE-240 did not reach its clinical endpoint of OS, knowledge of PD-L1 expression and CPS score can be highly instrumental for future studies and are urgently awaited [70]. Noteworthily, different cutoffs and definitions about PD-L1 positivity have been used in clinical trials, which might have limited the comparability of the findings [92].

High tumor mutational burden (TMB), generally defined as over 10 mutations $/ \mathrm{mb}$, or microsatellite instability (MSI) are hypothesized to be intrinsically immunogenic [93]. Hence, TMB or MSI status were predictive for response to therapy with PD-1 checkpoint-inhibitors in several tumor entities [66,94-96]. However, compared to other tumor entities, HCC mainly has a low TMB of $<10$ mutations $/ \mathrm{Mb}^{\text {low }}$ and MSI rates below 1\% [75,96-99]. Given the low prevalence and only limited predictive ability of TMB, it emphasizes the need for more comprehensive molecular biomarkers [97].

Circulating immune cells and corresponding expression of checkpoint molecules have been intensively evaluated as predictive biomarker. Isolation and subsequent characterization would enable a closer and non-invasive therapy monitoring, which is not possible using tissue samples. However, only one study could identify an association of circulating immune cells and response to therapy so far. A higher expression of $\mathrm{CD} 4^{+} \mathrm{PD} 1^{+}$cells in circulating peripheral blood mononuclear cells (PBMC) at baseline may predict a better response to tremelimumab treatment in HCC patients [100]. However, more recently, results from several clinical trials suggest that induction of a CD8 T cell response after CTLA-4 priming might enhance the anti-tumor efficacy of PD-1 inhibition [46]. This interesting observation should be pursued in future studies.

Furthermore, high soluble PD-L1 levels are associated with a poor prognosis in HCC patients [101]. However, soluble PD-L1 could not be shown to be predictive under immunotherapy in HCC in contrast to other tumor entities [102,103].

Finally, studies have shown that the microbiome influences the immune system. Mice with liver tumors showed a better immune response and lower tumor burden when treated with antibiotics that reduced the overall bacterial burden in the gut but favor Clostridium scindens. Reduction of bacteria through antibiotics alters the composition of bile acids, which subsequently resulted in increased 
infiltration of NKT cells with anti-tumor function into the liver. On the other hand, gut microbiota has been shown to promote obesity-associated liver cancer by driving prostaglandin E2 (PGE2) production through higher expression of COX2. PGE2 eventually suppressed antitumor immunity and resulted in higher tumor burden of obesity-driven HCC [104]. Several studies have shown that the microbiome influences not only immune cells but also the efficiency of immunotherapy. Anti-PD1 therapy could be significantly improved by combing it with oral administration of Bifidobacterium, which resulted in reduced tumor growth of B16.SIY melanoma tumors [105]. Another study found the fecal transplantation of Akkermansia muciniphia can restore efficacy of anti-PD-1 immunotherapy, which was mediated by increasing the recruitment of CCR9 ${ }^{+} \mathrm{CXCR}^{+} \mathrm{CD} 4^{+} \mathrm{T}$ lymphocytes [105]. In human melanoma, anti-CTLA-4 therapy was associated with outgrowth of Bacteroides fragilis. Oral feeding of Bacteroides fragilis in germ-free mice resulted in restored therapeutic response to anti-CTLA-4 treatment [106]. Notably, a recent study focused on fecal samples from patients under immunotherapy as a predictive parameter and revealed a higher species richness in responding patients than in non-responders [107]. Furthermore, other studies suggest an association between commensal microbial composition and therapy response to immune therapy treatment in melanoma as well as HCC, whereas patient numbers were very limited $(N=8)[107,108]$. Thus, data on the microbiome should be assessed as adjuvant information in future studies to identify its potential as a biomarker [109]. Data is mixed but it is clear that the composition of bacteria in the gut has influence and might predict response to immunotherapy and cannot be neglected. Sample acquisition in a hospitalized setting seems easy so that specifically response assessment and subsequent alteration of the treatment strategy based on the microbiome status seems to be reasonable.

Overall, while not yet conclusive in HCC, these findings provide the first mechanistic explanations of tumor cell biodiversity and why some patients may respond to therapy and others do not [86].

\subsection{Molecular Subtyping of HCC}

In the past, exome sequencing enabled a precise description of the mutational landscape in HCC including the identification of the most relevant oncogenic drivers (TERT, TP53, CTNNB1, AXIN1, ARID1A and ARID2) [18,110,111]. In $28 \%$ of all HCCs, potential targetable mutations were identified [112]. However, despite strong efforts, none of these potential biomarkers showed a significant survival benefit and could be implemented in clinical trials [18].

Analysis of the immune composition as well as the transcriptomic profile in HCC lead to the classification of inflamed "hot" tumors and non-inflamed "cold" tumors based on the presence of $\mathrm{T}$ cells, macrophages, B cells, PD1 signaling, and cytotoxic cytokines. Interestingly, "cold" tumors co-occur with WNT/CTNNB1 as well as chromosomal alterations of the tumor $[18,111,113]$.

A retrospective analysis of genomic alterations of HCC patients undergoing immunotherapy revealed WNT1/CTNNB1 mutations to be associated with lower disease control rates $(0 \%$ vs. $53 \%)$, shorter median progression free survival (PFS) (2.0 vs. 7.4 months), and shorter median OS [18,114]. This possible CTNNB1 immune excluded class could recently be confirmed in a translational mouse model [114,115]. Upregulation of $\beta$-catenin leads to an immune exclusion of the tumor and also resistance to anti-PD-1 therapy. These results conclusively illustrate, that other therapy modalities might be more suitable for cold or immune excluded and, potentially, other subclasses of HCC, and challenges the design of recent clinical investigations. In this context, molecular stratification of patients will become increasingly important and should be mandatory for future clinical trials.

\section{Combination Treatments to Improve Therapy Response in HCC}

\subsection{Combination Therapies of Checkpoint Inhibitors}

Given that the response to immunotherapy is restricted to $15-30 \%$ of the patients, the majority of the patients are not objectively responding or show a primary resistance to ICI. After initial studies on effectiveness of immunomodulatory drugs, new studies are focusing on mechanisms to increase 
therapy response [42]. The rationale behind combinations therapies is based on synergistic effects by CTLA4 induction followed by PD-1/PD-L1 blockade (Figure 2). Combination of different ICI blocks immune cell activation at different steps in their activation process. CTLA4 increases CD8 T cell activation in the priming phase in the lymph node as well as CD8 cell infiltration into the tumor. This enhances the effect of PD-1/PD-L1 blockade in the tumor microenvironment. The number of pretreatment or treatment induced intratumoral $\mathrm{T}$ cell infiltration correlates with clinical response to therapy, which emphasizes that the crucial factor for response to immunotherapy lies in releasing tumor-specific T cells [116].

The combination of checkpoint inhibitors antiPD-1/anti-PD-L1 plus anti-CTLA-4 antibodies have shown promising response rates of $40-60 \%$ in melanoma, NSCLC, and renal cancer [132-134]. Based on this, combination therapies of CTLA-4 and PD-1/PD-L1 blockade are currently under investigation [42].

In HCC, these combinations are also being actively pursed in clinical trials [45,135]. ORR rates for advanced non-resectable HCC in a phase II clinical trial (durvalumab (anti-PD-L1) and tremelimumab (anti-CTLA-4)) have been reported recently as $22 \%$ with $35 \%$ of the patients showing adverse events [136]. The phase III clinical trial (HIMALAYA) is currently underway [45]. However, the CHECKMATE-040 trial investigating nivolumab and ipilimumab could show overall response rates of 32\% [42]. Further studies are required focusing on effectiveness versus increased adverse events. For a detailed list see Table 2.

\subsection{Combination Therapies of Checkpoint Inhibitors and Anti-Angiogenesis}

Another approach to enhance response to therapy explores additive effect of MKIs and ICI. It is well known that high VEGF levels in the TME modulate immunosuppressive $\mathrm{T}_{\text {regs, }}$ macrophages and MDSCs, whereby promoting tumor growth [86]. Anti-angiogenic effects of MKIs mediated by VEGF inhibition can synergistically enhance the anti-tumor effects of ICI. Furthermore, Sorafenib effectively inhibits macrophage migration, macrophage induces epithelial-mesenchymal transition as well as macrophage-NK cell crosstalk in the liver $[34,137]$. In line with this, combination of pembrolizumab (anti PD-1) and Lenvatinib (MKI) reduced the secretion of immunosuppressive cytokines such as TGF- $\beta$ and IL-10 and inhibited expression of PD-1 and Tim3, which enhanced antitumor immune response in a mouse model of hepatocarcinogenesis [138].

Further, the IMbrave150 phase III clinical trial confirmed the promising effects for the combination of atezolizumab plus bevacizumab, a direct VEGF inhibitor, in a first line treatment in HCC patients [48]. The experimental arm showed an ORR 33\% versus 13\% for sorafenib arm and median OS at 12 months was $67 \%$ versus $55 \%$. These results have led to an FDA approval for the combination of bevacizumab and atezolizumab for advanced HCC and will likely become the new standard of care in advanced HCCs. Many other combination studies are currently underway (Table 2). Similar to the findings from the IMbrave150 study, ORR for pembrolizumab plus Lenvatinib have been reported $36 \%$ in a phase Ib clinical trial. Notably, $36 \%$ had serious treatment related adverse events [122]. Nevertheless, combination of ICI and MKIs show promising anti-tumor response rates. Many other studies are currently underway. For a detailed list see Table 2. 
Table 2. Summary of clinical trials for immunotherapy (mono- and combination therapies/completed and ongoing) in HCC.

\begin{tabular}{|c|c|c|c|c|c|c|c|c|c|}
\hline Author (Year) & Phase/Trial Name & Target & Therapy Regimen & ORR & $\begin{array}{c}\text { PFS } \\
\text { (Months) }\end{array}$ & pts & DCR & $\begin{array}{c}\text { Additional } \\
\text { Information }\end{array}$ & Status \\
\hline \multicolumn{10}{|l|}{ Monotherapy } \\
\hline Sangro (2013) [44] & II & CTLA-4 & Tremilimumab & $17.6 \%$ (3 PR) & 6.48 & 21 & $76.4 \%$ & & completed \\
\hline $\begin{array}{l}\text { El-Khoueiry (2017) } \\
\text { [40] }\end{array}$ & $\begin{array}{c}\text { II } \\
\text { CHECKMATE-40 } \\
\text { Second line }\end{array}$ & PD-1 & Nivolumab & $20 \%(3 \mathrm{CR}, 39 \mathrm{PR})$ & 4.0 & 214 & $\begin{array}{c}64 \% \\
\text { (37\% over } 6 \\
\text { months) }\end{array}$ & $\begin{array}{c}\text { PD-1 } 1^{\text {high }} \text { ORR } 26 \% \text {, } \\
\text { PD- } 1^{\text {low }} \text { ORR } 19 \% \text {, } \\
9 \text { months OS } 74 \% \text {, KM } \\
\text { median not reached yet }\end{array}$ & completed \\
\hline Zhu (2018) [41] & $\begin{array}{c}\text { II } \\
\text { KEYNOTE-224 } \\
\text { Second line }\end{array}$ & PD-1 & Pembrolizumab & $17 \%$ (1 CR, $17 \mathrm{PR})$ & NR & 104 & $64 \%$ & $\begin{array}{l}\text { Positive correlation of } \\
\text { ORR and TPS score }\end{array}$ & completed \\
\hline Finn (2020) [117] & $\begin{array}{c}\text { III } \\
\text { KEYNOTE-240 } \\
\text { Second line }\end{array}$ & PD-1 & Pembrolizumab & $\begin{array}{c}18.3 \% \text { (6 CR, } 45 \\
\text { PR) }\end{array}$ & 3.0 & 413 & $\begin{array}{c}62.2 \%,(31 \% \\
\text { over } 6 \text { months) }\end{array}$ & OS 13.9 months & negative trial \\
\hline Yau (2019) [73] & $\begin{array}{c}\text { III } \\
\text { CHECKMATE459 } \\
\text { First line }\end{array}$ & PD-1 & Nivolumab vs. Sorafenib & $\begin{array}{c}15 \%(14 \mathrm{CR}, 43 \\
\text { PR) }\end{array}$ & 3.7 & 743 & - & $\begin{array}{l}\text { PD-L1 }{ }^{\text {high }} \text { ORR } 28 \% \\
\text { PD-L1 } 1^{\text {low }} \text { ORR } 12 \%\end{array}$ & negative trial \\
\hline Qin (2019) [118] & $\begin{array}{c}\text { III } \\
\text { Rationale } 301 \\
\text { First line }\end{array}$ & PD-L1/PD-L2 & Tislelizumab vs. Sorafenib & - & - & - & - & & ongoing \\
\hline $\begin{array}{c}\text { Exposito (2018) } \\
\text { [119] }\end{array}$ & $\begin{array}{c}\text { III } \\
\text { CHECKMATE-9DX } \\
\text { Adjuvant }\end{array}$ & PD-1 & Nivolumab & - & - & 530 & - & & ongoing \\
\hline \multicolumn{10}{|c|}{ Combination of immunotherapies } \\
\hline Yau (2019) [42] & $\begin{array}{c}\text { I/II } \\
\text { CHECKMATE-40 }\end{array}$ & $\begin{array}{l}\text { PD-1 + } \\
\text { CTLA-4 }\end{array}$ & Nivolumab + Ipilimumab & $32 \%(4 \mathrm{CR}, 12 \mathrm{PR})$ & - & 148 & $54 \%$ & $\begin{array}{l}12 \text { months OS } 61 \% \\
\text { PD-1 }^{\text {high }} \text { and PD- } 1^{\text {low: }} \\
\text { no difference }\end{array}$ & ongoing \\
\hline Kelley (2020) [46] & $\mathrm{I} / \mathrm{II}$ & $\begin{array}{l}\text { PD-L1, } \\
\text { CTLA-4 }\end{array}$ & $\begin{array}{l}\text { Durvalumab + } \\
\text { Tremelimumab }\end{array}$ & $22 \%$ & - & 75 & & Median OS 18.7 months & ongoing \\
\hline $\begin{array}{l}\text { Abou-Alfa } \\
\text { (2018) [45] }\end{array}$ & $\begin{array}{c}\text { III } \\
\text { HIMALAYA }\end{array}$ & $\begin{array}{l}\text { PD-L1, } \\
\text { CTLA-4 }\end{array}$ & $\begin{array}{c}\text { Durvalumab }+ \\
\text { Tremelimumab vs. } \\
\text { Durvalumab vs. Sorafenib }\end{array}$ & - & - & - & - & & ongoing \\
\hline Kaseb (2019) [120] & $\begin{array}{c}\text { II } \\
\text { Neoadjuvant }+ \\
\text { adjuvant }\end{array}$ & PD-1, CTLA-4 & Nivolumab + Ipilimumab & $37.5 \%$ (3 CR) & - & 8 & - & & ongoing \\
\hline
\end{tabular}


Table 2. Cont.

\begin{tabular}{|c|c|c|c|c|c|c|c|c|c|}
\hline Author (Year) & Phase/Trial Name & Target & Therapy Regimen & ORR & $\begin{array}{c}\text { PFS } \\
\text { (Months) }\end{array}$ & pts & DCR & $\begin{array}{l}\text { Additional } \\
\text { Information }\end{array}$ & Status \\
\hline \multicolumn{10}{|c|}{ Combination with MKI } \\
\hline Bang (2019) [121] & $\mathrm{Ib}$ & $\begin{array}{l}\text { PD-L1 + } \\
\text { VEGF }\end{array}$ & $\begin{array}{l}\text { Durvalumab + } \\
\text { Ramucirumab }\end{array}$ & $\begin{array}{c}11 \% \\
(3 \mathrm{CR}+\mathrm{PR})\end{array}$ & 4.4 & 28 & $61 \%$ & $\begin{array}{c}\text { PD-L1 }{ }^{\text {high }} \text { ORR } 18 \%, \\
\text { DCR } 73 \%\end{array}$ & ongoing \\
\hline Zhu (2020) [122] & $\begin{array}{c}\mathrm{lb} \\
\text { KEYNOTE } 524 \\
\text { First line }\end{array}$ & PD-1 + MKI & $\begin{array}{l}\text { Pembrolizumab }+ \\
\text { Lenvatinib }\end{array}$ & $\begin{array}{c}36 \% \\
(1 \mathrm{CR}, 35 \mathrm{PR})\end{array}$ & 8.6 & 30 & $60 \%$ & & ongoing \\
\hline Llovet (2019) [123] & $\begin{array}{c}\text { III } \\
\text { LEAP002 } \\
\text { First line }\end{array}$ & PD-1 + MKI & $\begin{array}{c}\text { Lenvatinib + } \\
\text { Pembrolizumab vs. } \\
\text { Lenvatinib }\end{array}$ & - & - & 750 & - & & ongoing \\
\hline \multirow[t]{2}{*}{ Xu (2019) [124] } & $\begin{array}{c}\text { I } \\
\text { Second line }\end{array}$ & PD-1 + MKI & Camrelizumab + Apatinib & $\begin{array}{c}50 \% \\
(8 \mathrm{PR})\end{array}$ & 5.8 & $\begin{array}{l}39(16 \\
\text { HCC) }\end{array}$ & $93.8 \%$ & OS NR & ongoing \\
\hline & $\begin{array}{c}\text { II } \\
\text { IMMUNIB } \\
\text { First line }\end{array}$ & PD-1 + MKI & Nivolumab + Lenvatinib & - & - & est. 50 & - & & ongoing \\
\hline $\begin{array}{c}\text { Pishvaian (2018) } \\
\text { [125] }\end{array}$ & $\mathrm{Ib}$ & $\begin{array}{l}\text { PD-L1 + } \\
\text { VEGF }\end{array}$ & $\begin{array}{l}\text { Atezolizumab }+ \\
\text { Bevacizumab }\end{array}$ & $\begin{array}{c}34 \% \\
(1 \mathrm{CR}, 22 \mathrm{PR}) \\
\end{array}$ & 14.9 & 68 & $\begin{array}{l}78 \% \text { ( } 50 \% \text { over } 6 \\
\text { months) }\end{array}$ & & ongoing \\
\hline Finn (2018) [48] & $\begin{array}{c}\text { III } \\
\text { IMbrave150 } \\
\text { First line }\end{array}$ & $\begin{array}{l}\text { PD-L1 + } \\
\text { VEGF }\end{array}$ & $\begin{array}{c}\text { Atezolizumab }+ \\
\text { Bevacizumab vs. Sorafenib }\end{array}$ & $\begin{array}{c}33 \% \\
(33 \mathrm{CR}, 75 \mathrm{PR})\end{array}$ & 6.8 & 325 & $72.3 \%$ & & ongoing \\
\hline Yau (2020) [47] & $\begin{array}{c}\text { II } \\
\text { CHECKMATE } 40\end{array}$ & $\begin{array}{l}\text { PD-1 + } \\
\text { CTLA-4 + } \\
\text { MKI }\end{array}$ & $\begin{array}{c}\text { Nivolumab + Cabozantinib } \\
\text { vs. Nivolumab + } \\
\text { Ipilimumab + } \\
\text { Cabozantinib }\end{array}$ & $26 \%$ (9 PR) & 6.8 & 71 & $83 \%$ & $\begin{array}{l}71 \% \text { grade III-IV AEs, } \\
\text { discontinuation in } 20 \%\end{array}$ & ongoing \\
\hline Kudo (2019) [126] & $\begin{array}{c}\mathrm{Ib} \\
\text { VEGF Liver } 100 \\
\text { First line }\end{array}$ & PD-L1 + MKI & Avelumab + Axitinib & $13.6 \%$ & 5.5 & 22 & $68.2 \%$ & OS 12.7 months & ongoing \\
\hline Kelley (2019) [127] & $\begin{array}{c}\text { III } \\
\text { COSMIC-312 } \\
\text { First line }\end{array}$ & PD-L1 + MKI & $\begin{array}{c}\text { Atezolizumab }+ \\
\text { Cabozantinib vs. Sorafenib }\end{array}$ & - & - & 640 & - & & ongoing \\
\hline Knox (2019) [128] & $\begin{array}{c}\text { III } \\
\text { EMERALD 2 } \\
\text { Adjuvant }\end{array}$ & $\begin{array}{l}\text { PD-L1 + } \\
\text { VEGF }\end{array}$ & $\begin{array}{l}\text { Durvalumab + } \\
\text { Bevacizumab }\end{array}$ & - & - & - & - & & ongoing \\
\hline
\end{tabular}


Table 2. Cont.

\begin{tabular}{|c|c|c|c|c|c|c|c|c|c|}
\hline Author (Year) & Phase/Trial Name & Target & Therapy Regimen & ORR & $\begin{array}{c}\text { PFS } \\
\text { (Months) }\end{array}$ & pts & DCR & $\begin{array}{c}\text { Additional } \\
\text { Information }\end{array}$ & Status \\
\hline \multicolumn{10}{|c|}{ Combination with locoregional therapy } \\
\hline Duffy (2017) [43] & $\mathrm{I} / \mathrm{II}$ & $\begin{array}{c}\text { CTLA-4 + } \\
\text { locoregional }\end{array}$ & $\begin{array}{c}\text { Tremilimumab + } \\
\text { TACE/RFA }\end{array}$ & $26.3 \%$ & 7.4 & 32 & - & OS 12.3 months & completed \\
\hline Sangro (2020) [129] & $\begin{array}{l}\text { III } \\
\text { EMERALD } 1 \\
\text { adjuvant }\end{array}$ & $\begin{array}{c}\text { PD-L1 + } \\
\text { VEGF + } \\
\text { locoregional }\end{array}$ & $\begin{array}{c}\text { Durvalumab + } \\
\text { Bevacizumab + TACE }\end{array}$ & - & - & 600 & - & & ongoing \\
\hline \multirow{3}{*}{$\begin{array}{c}\text { Charalampos (2019) } \\
\text { [130] }\end{array}$} & $\begin{array}{c}\text { II } \\
\text { adjuvant }\end{array}$ & $\begin{array}{c}\text { PD-L1+ } \\
\text { CTLA-4 + } \\
\text { locoregional }\end{array}$ & $\begin{array}{c}\text { Durvalumab + } \\
\text { Tremilimumab + } \\
\text { TACE/RFA/cryoablation }\end{array}$ & $\begin{array}{l}20 \% \\
(2 \mathrm{PR})\end{array}$ & 7.8 & $\begin{array}{l}22(10 \\
\mathrm{HCC})\end{array}$ & $60 \%$ & OS 15.9 months & ongoing \\
\hline & $\begin{array}{c}\text { II } \\
\text { IMMULAB }\end{array}$ & $\begin{array}{c}\text { PD-1 + } \\
\text { locoregional }\end{array}$ & $\begin{array}{c}\text { Pembrolizumab + } \\
\text { RFA/MWA }\end{array}$ & - & - & - & - & & ongoing \\
\hline & $\begin{array}{c}\text { II } \\
\text { PLTHCC }\end{array}$ & $\begin{array}{l}\text { PD-1 + MKI+ } \\
\text { locoregional }\end{array}$ & $\begin{array}{c}\text { Immunotherapy + } \\
\text { Lenvatinib + TCAE }\end{array}$ & - & - & - & - & & ongoing \\
\hline Popovic (2019) [131] & $\begin{array}{c}\text { Ib } \\
\text { CaboNivo } \\
\text { Neoadjuvant in } \\
\text { locally advanced } \\
\text { HCC }\end{array}$ & $\begin{array}{l}\text { PD-1 + MKI + } \\
\text { resection }\end{array}$ & Nivolumab + Cabozantinib & - & - & 15 & - & & ongoing \\
\hline
\end{tabular}




\subsection{Combination of Immunotherapy and Locoregional Therapy}

A different approach to improve the response is to modulate the immunogenicity of tumors or to boost the immune system by combination of locoregional and/or radiotherapy with immunotherapy. This approach is based on releasing tumor antigens through cell death induced by locoregional therapy, which subsequently improves immunotherapy due to better antigen presentation. Thus, this combination is also discussed for neoadjuvant settings, when tumor burden is still high. In particular, antigen release and immunological response after irradiation has been extensively studied [139-141].

In 2004, de Broke et al. [142] could already show that RFA plus blocking CTLA-4 with tremelimumab causes a strong and durable antitumor response in a mouse model of B16 OVA melanoma cells. The same group showed that cryoablation and radiofrequency enables antigen loading of dendritic cells, which induced antitumor immunity [143], indicating that locoregional therapies could have more effects than just the local tumor elimination. The immunomodulatory effects caused by local therapies are of particular interest in the era of immunotherapies [144]. Different types of cell death can cause an immunogenic or non-immunogenic influence on the environment, whereas immunogenic cell death includes the release of calreticulin and other proteins of the endoplasmatic reticulum, which leads to activation of dendritic cells and improved tumor-antigen presentation for cytotoxic T cells [144]. A classical immunogenic cell death inducing chemotherapeutic is doxorubicin, which is most commonly used in TACE procedures in HCC patients [145]. MDSCs, which are increased in HCC patients, stimulate $T_{\text {regs }}$ and correlate with HCC progression, $[146,147]$ are decreased after RFA. However, patients with increased frequencies were more likely to recur after treatment. The effect of TACE or RFA on T cells seems to be stronger than surgery alone. After locoregional therapy, patients had a significant increase in GPC3 specific CTLs compared to patients undergoing surgery [140]. Radioembolization (Y90) on the other hand seems to have a sustained local as well as systemic immune response, that could be shown by an increase in TNF $\alpha$ in CD4, CD8 T cells, and APCs. The group could further demonstrate a prediction model based on peripheral blood samples before Y90 therapy [148].

However, response immunological response rates after locoregional therapy alone was not durable enough to prevent recurrence, underlining the potential of combination with immunotherapy [54]. The first combination therapy of tremelimumab and TACE, RFA, or cryoablation showed a good tolerability and an increase in intratumoral accumulation of CD8 T cells with good clinical response [43]. Remarkably, only lesions that were not directly treated were counted as tumor response, i.e., "abscopal effect" [43]. One combined clinical trial for HCC and CCA is investigating a combined immune checkpoint inhibition with ablative therapies (Durvalumab, Tremelimumab, TACE, RFA OR Cryoablation) (NCT02821754) [130]. For a detailed list of current clinical trials see Table 2.

While preclinical and early clinical data provides a clear rational for combination therapies, several open questions remain. In the context of combination therapy, the timing and sequence of corresponding therapies and identification of the best locoregional therapy in combination with the best immunotherapy are of particular interest. Further translational studies are also needed to improve the understanding of the exact molecular mechanisms involved in the response or failure of these combinations.

\section{Translational Studies to Overcome Resistance to Immunotherapies}

To detect molecular and cellular predictors of positive response to immunotherapy, animal models are widely employed in preclinical investigations, particularly syngeneic, genetically engineered, and humanized mice [149]. All of them harbor certain advantages and disadvantages, which should be carefully considered to accurately address the respective questions concerning immunotherapy.

\subsection{Checkpoint Inhibitors}

Investigation of immune checkpoint inhibitors using suitable models represents an important aspect of translational cancer research and is required for transitioning of crucial findings from bench 
to bedside. Detailed investigations on factors that are assisting immune evasion and contributing to the failure of classic chemotherapy are crucial [150]. Importance of CTLA-4 and PD-1/PD-L1 was thoroughly investigated in pre-clinical and early clinical models. Results revealed interesting and useful data for further translational implications and supported currently-used strategies in clinical trials [151,152].

Study of Brown et al. [153] tried to address mechanism of adaptive resistance to immunotherapy in the context of CTLA-4 checkpoint blockade. Results of this important study suggest that induction of Indoleamine 2,3-dioxygenase 1 (IDO1) typically appears in HCCs that are resistant to anti-CTLA-4 treatment, and that it is regulated in an IFN- $\gamma$ dependent manner. These observations emphasized the importance of IDO1 as a regulator of adaptive resistance against anti-CTLA-4 treatment. Thus, combined therapy of IDO1 inhibitor and anti-CTLA-4 treatment emerges as a rational approach to improve the checkpoint-based treatments for the resistant types of HCC (Figure 2) [153]. In addition to increasing numbers of studies related to CTLA-4 therapy resistance, many new investigations aimed to delineate the fundamental mechanisms of PD-1/PD-L1-dependant immune tolerance in HCC [71,154]. In a chemically-induced HCC mouse model, exhaustion of tumor-antigen-specific CD8 ${ }^{+}$ $\mathrm{T}$ cells, accumulation of PD- $1 \mathrm{CD} 8^{+} \mathrm{T}$ cells as well as $\mathrm{T}_{\text {regs }}$ was reported at the time of late tumor progression [71]. These findings encouraged authors to investigate a combination therapy of sunitinib and anti-PD-1 antibodies. This approach not only repressed adverse tumor features like immune evasion, but also directly reduced tumor burden and activated antitumor immunity [71].

To overcome immune tolerance, it is further important to explore more precise approaches to identify molecular components involved in immune evasion in HCC [155-157]. Polyinosinicpolycytidylic acid (polyIC), a double-stranded RNA, was firstly introduced as a molecule with potent liver tumor-inhibitory role only at the pre-cancer stage [155]. However, the potency of polyIC to treat advanced HCC was identified in a later study when it was combined with anti-PD-L1 antibody [156]. The mechanism of therapy response based on the ability of polyIC to enhance accumulation and activation of innate immune cells in the liver, particularly natural killer (NK) cells and macrophages, as well as to modulate adaptive immune functions by upregulation of PD-L1 in liver sinusoidal endothelial cells. These conditions sensitized the hepatic response to PD-L1 blockade and induced accumulation of active $\mathrm{CD}^{+} \mathrm{T}$ cells (Figure 2) [156]. These studies clearly imply that modulation of specific pathways can lead to sensitization of the tumors to PD-L1 blockade and improve the response in HCC mouse models. These interesting findings should be pursued in future pre-clinical and clinical trials.

Further efficacy improvements of checkpoint inhibitors could be achieved through disruption of pathways involved in epigenetic regulation. For example, combination of histone deacetylase inhibitor belinostat with anti-CTLA-4, or combination of anti-CTLA-4 plus anti-PD-1 antibodies could lead to complete tumor rejection in a mouse HCC model [158]. Moreover, another study suggests that PD-L1 blockade and SIRT7 inhibition could be a more efficient clinical option to target HCC (Figure 2) [159]. Overall, these results provide a rationale for testing epigenetic modulators in combination with checkpoint inhibitors to enhance their therapeutic activity in patients with HCC.

All together, these animal studies clearly demonstrate the importance of the cellular composition and balance of pro- and anti-tumor immune cells for effectiveness of immunotherapy. Results clearly delineate capacity of epigenetic regulators to improve the immunotherapy response.

\subsection{Application of Neoantigens and Oncolytic Viruses in Immunotherapy}

One of the strategies to induce a positive immune response against cancer is the activation of $\mathrm{CD}^{+} \mathrm{T}$ cells, either by antigen-presenting or by tumor cells. In this context, particularly interesting are the neoantigens that arise as a result of tumor-specific mutations, which could be effectively used for development of novel therapeutic approaches [52]. An effective way to increase neoantigen presentation to $\mathrm{CD} 8^{+} \mathrm{T}$ cells in the tumor/-microenvironment is induction of cellular death by using various approaches, such as local ablation therapy or oncolytic viruses (OV) $[53,160]$. 
In a recent study, release of neoantigens was induced in an orthotopic mouse HCC model by applying image-guided stereotactic radiation. The treatment generated insufficient $\mathrm{CD}^{+} \mathrm{T}$ cell mediated immune response due to feedback inhibition of T cells by increased PD-L1 expression on macrophages. Interestingly, antitumor effect was enhanced when combining stereotactic radiation with anti-PD-1 treatment. This approach promoted adaptive immunity and infiltration of $\mathrm{CD}^{+}$cytotoxic $T$ cells in the tumor, but only in a transient manner [72].

Great potential of OVs for the cancer treatment has been recognized in preclinical animal models as well as in human cancer patients [161,162]. Particularly interesting is application of oncolytic viruses in immunotherapies, which are specifically designed to selectively lyse cancer cells and to induce specific anti-tumor immunity. However, despite of a number of OVs that were examined in the preclinical studies, a low number entered into the clinical trials [161,162]. The most advanced of them is JX-594 (Pexa-Vec), which has entered a phase 3 randomized clinical study (PHOCUS). In this trial, the main objective is to determine if treatment with JX-594 and sorafenib increases survival in patients with advanced HCC who did not previously receive systemic therapy (NCT02562755). Therefore, development of new preclinical models to evaluate the effects of oncolytic viruses in HCC will pave the road for advanced clinical trials and speed up development of new cancer treatments. In line with that, new generations of OVs have been developed with greater potential to specifically target tumor cells and stimulate the immune response [163,164]. Recently, Nakatake et al. [163] examined the antitumor activities and immune response of third-generation HSV T-01 in HCC cell lines and mouse xenograft models. Application of the virus successfully led to increased expression of MHC class I molecules on tumor cells, which further stimulated $\mathrm{CD}^{+} \mathrm{T}$ cell-mediated immune response. Importantly, viral treatment induced only antitumor effects without affecting normal cells, demonstrating great potential and specificity of this approach [163]. The capability of HSV-1 was further examined in a study where a novel HSV-1 vector, Ld0-GFP, was developed. Administration of the vector clearly showed increased tumor selectivity and oncolytic capacity against HCC by enhancing cell apoptosis in different mouse models. Overall, viral-induced oncolysis provoked strong immunogenic cell death by activating the immunogenic cell death pathway [165]. Despite the above mentioned OVs, several other viruses have also been explored in the context of HCC.

Overall, both exploration of neoantigens and direct tumor lysis by OV, show great translational value, as some of the investigated models and are currently investigated in clinical trials.

\subsection{Targeting HCC Biomarkers-Vaccines, Antibodies, and Cytokines}

Targeting a specific marker or a component of immune defense in HCC could be an effective way to overcome resistance commonly observed with classic chemotherapies [111]. New opportunities are emerging as specialized anti-cancer vaccines are developed and tested in animal models [166]. Most compelling are the vaccines that specifically target HCC-associated markers such as AFP and GPC3 (approach known as "antigen-defined") [167-169]. Many studies exploited the potential of AFP for designing an effective HCC vaccine [170-173]. In order to induce immune response, different approaches such as application of AFP plasmid DNA, dendritic cell (DC) transduction with viral vectors, or a combination of AFP with heat shock proteins have been evaluated [170-173]. However, the most promising results of AFP cancer immunization were achieved through production of epitope-optimized AFP, which effectively activated CD $8^{+} \mathrm{T}$ cells and generated potent antitumor effects in HCC mouse model [174]. Several studies tried to target the activation of GPC3, a glycoprotein overexpressed in many HCC tissues, in order to design an effective vaccine [169]. Preclinical evidence suggests that intravenous injection of the GPC3-coupled lymphocytes can induce a strong anti-HCC effect by regulating systemic and local immune responses [169].

In addition to the above-mentioned vaccine-based approaches, a growing number of antibodies are produced to eradicate or neutralize specific molecular or cellular targets [61]. Several antibodies were also successfully targeted including GPC3, a member of the TNF receptor family CD137, transmembrane four L6 family member 5 protein, and fibrinogen-like protein 1 [175-177]. These 
investigations also demonstrated various degrees of anti-tumor and immune-modulatory capacity. In addition, immune modulation directed against liver cancer can be initiated by a release of cytokines involved in cellular antitumor response $[178,179]$. For instance, IL-33 release in murine HCC showed to markedly inhibit tumor growth via activated $\mathrm{CD} 4^{+}$and $\mathrm{CD} 8^{+} \mathrm{T}$ cells, in IL-33-expressing tumor-bearing mice, while IL-18/IL-12 cytokine therapy was effective in tumor regression prompted by induction of NK cells [178-180].

Taken together, development of different strategies to target specific HCC biomarkers and to modulate cytokine release shows big potential in immunotherapy of HCC.

\subsection{Adoptive Cell Transfer and CAR T Cells}

The basic principle of adoptive cell transfer is to disrupt the immune tolerance of tumors and, consequently, to suppress the growth and survival of tumor cells. This is achieved when lymphocytes are extracted from the patients, with the purpose of modification and amplification in vitro, and, subsequently, transferred back into the patient. This method enhances the overall specific antitumor effect [181]. Most of the recent studies on adoptive cell transfer were focused on targeting GPC3 [182]. In a seminal study, GPC3-specific CD8 ${ }^{+} \mathrm{T}$ cells were engineered and subsequent antitumor capabilities in HCC xenograft mice were tested. This approach showed only partial response, as CD8 ${ }^{+}$ $\mathrm{T}$ cells were only able to slow down tumor growth in whole-body irradiated mouse model. Further, immunodeficient model displayed higher suppression of tumor growth. In this model, failure of significant tumor response was consequence of a lack of $\mathrm{CD} 8^{+} \mathrm{T}$ cell infiltration into the tumor and by mosaic-pattern of GPC3 expression which could be enhanced in future studies [182].

However, more recently, CAR T cell-based therapy gained increasing attention as a potentially more efficient method to target tumor cells [183-186]. Earlier studies have already proven the potential of CAR $\mathrm{T}$ cells to effectively target GPC $3^{+}$HCC cells in vivo. Anti-GPC3 CAR T cells successfully suppressed tumorigenesis in subcutaneous tumors and significantly affected tumor growth in subcutaneous and orthotopic xenografts [183]. Similar observation was noted in a patient-derived xenograft model. CAR $T$ cells directed against GPC 3 eradicated tumors from patient derived xenografts that showed less aggressive phenotype and lacked PD-L1 expression, while on the contrary, GPC3 CAR T cells were less potent in aggressive tumors with high PD-L1 expression. This all emphasized the potential of combination therapy with immune checkpoint inhibitors [185]. Except of combining GPC3-CAR T cells with checkpoint inhibitors, Wu et al. investigated potential application of sorafenib to induce additive effects. The authors reported that sorafenib enhanced the antitumor effects of CAR T cells, partially by promoting IL12 secretion by TAMs as well as promotion of apoptosis in immunocompetent and immunodeficient mouse models of HCC [186]. It is also important to mention that NK cells were investigated in the context of chimeric antigen receptor with promising results. This makes NK cell-based therapy as a novel treatment option for patients with GPC $3^{+}$HCC [184].

Major studies on CAR T cells in HCC have been conducted with the main focus on GPC3. They shed more light on this complex topic and provided evidence for further investigations to define new targets for CAR T treatments. However, heterogeneous intra- and inter-tumoral expression of surface antigens as targets for CAR T-based approaches including GPC3 severely complicate this approach in human HCC.

\subsection{Targeting Cross-Communication between MDSCs and the TME}

The chronically altered tumor microenvironment in HCC, particularly liver fibrosis, significantly shapes and modulates the course of HCC development specifically by reprogramming an immunosuppressive mechanism [187]. Accumulation of monocytic MDSCs (M-MDSC) in fibrotic tumor microenvironment in orthotopic mouse model can significantly reduce the number of TILs and increase tumorigenicity [187]. Recent investigations have revealed that contribution to immune tolerance and higher tumorigenicity was closely connected to the interaction between HSC from the fibrotic microenvironment and M-MDSC [187]. Namely, HSC could induce M-MDSC accumulation 
and immunosuppression through p38 MAPK-mediated enhancer reprogramming. Treatment with BET bromodomain inhibitor significantly reduced the level of M-MDSC and increased the level of tumor-infiltrating $\mathrm{CD}^{+} \mathrm{T}$ cell. When BET bromodomain inhibitor treatment was combined with anti-PD-L1 therapy, synergistic effects of the treatments led to tumor eradication and prolonged survival in this fibrotic-HCC mouse model. Therefore, targeting cross-communication (HSC-M-MDSC) in fibrotic liver could be a novel therapeutic strategy that could improve the efficacy of anti-PD-L1 therapy [187]. More evidence on how the response to PD-1/PD-L1 therapy could be further improved is presented by indirect modulation of IL-6 signaling, a major immune-modulatory cytokine in the liver [188]. Inhibition of $C c r k$ and CCRK/EZH2/NF- $\mathrm{kB} / \mathrm{IL}-6$ signaling cascade can bypass MDSC-mediated IFN- $\gamma^{+}$ $\mathrm{TNF}-\alpha^{+} \mathrm{CD}^{+} \mathrm{T}$ cell exhaustion and cause reduction in tumorigenicity. More importantly, inactivation of this signaling cascade paralleled with administration of anti-PD-L1 therapy could improve efficacy of checkpoint inhibitors in orthotopic HCC model and prevent immune evasion [188].

\subsection{Targeting MDSC, TAMs, and Innate Immunity Interaction for HCC Prevention}

Given the fact that macrophages promote HCC progression, therapeutic manipulation of this interaction is of major interest. This includes the inhibition of monocyte recruitment into the liver, polarization from M1 to M2 macrophages, inhibition of TAM associated cytokines, or direct inhibition of macrophages present in the tumor [189-192]. Blocking of CCL2-CCR2, which inhibits monocyte recruitment, was revealed to be effective in HCC mouse models. Namely, this approach increased tumor infiltrating macrophage numbers, promoted polarization into a M2 phenotype as well as enhanced a T cell antitumor response [193,194]. Moreover, treatment with Mi-RNA-26a effectively suppressed tumor growth by downregulating colony stimulating factor-1 (CSF1 or M CSF), which further inhibited macrophage recruitment [195]. Blocking of CSF1 and CSF1 receptor (CSF1R) has also been demonstrated to enhance the effectiveness of immune checkpoint inhibitors [157]. A recent study has reported that Osteopontin facilitates chemotactic migration and M2-like polarization of macrophages and promotes the expression of PD-L1 in HCC. These events are mediated via activation of CSF1-CSF1R pathway in macrophages, which leads to increase of immunosuppressive cytokine levels. Therefore, blocking the CSF1/CSF1R pathway could effectively prevent macrophage recruitment and M2 phenotype polarization, activate CD8 ${ }^{+}$T cells, and sensitize HCC to anti-PD-L1 immune checkpoint blockade (Figure 2) [157]. PLX3397 also inhibits CSF-1R and could prevent tumor growth in a murine HCC model by macrophage reprogramming [192]. Another agent, baicalin (a flanonoid), repolarized macrophages into M1-like macrophages in an orthotopic mouse model of liver cancer [196]. All these translational findings suggest potential combination therapies to reprogram the immunological TME.

From the perspective of innate immunity, NK cells are considered to be one of the key players in the prevention of HCC $[29,197]$. They exert a critical role in the antitumor immunity by modulating both, innate immunity as well as activation of adaptive immunity, by cross-talking with DCs and promoting a Thelper cell (Th)1-mediated immunity [29]. However, positive role of NK cells in fight against cancer has often been impaired in HCC $[198,199]$. It was already shown that MDSCs in patients with HCC suppress the innate immune system by diminishing autologous NK cell cytotoxicity and cytokine secretion. These events activate immune suppressor network and allow the tumors to evade the host immune response [200]. Earlier studies in mice determined that inhibition of NK cell cytotoxicity is contact-dependent, where MDSCs inhibit IL-2-mediated NK cell activation, by dysregulating Stat5 signaling [201]. More evidence on the dysregulation of NK cells by MDSCs was obtained in the liver cancer-bearing mouse model. Results showed that increased levels of MDSC directly influenced NK cell function by inhibition of their cytotoxicity and IFN- $\gamma$ production. The main mediator of NK cell suppression was membrane-bound TGF- $\beta 1$ on MDSC [29]. Taken together, disruption of interaction between MDSC and components of innate immunity, particularly NK cells, represents an attractive approach to confront development of HCC. 


\section{Conclusions and Future Direction}

Primary liver cancer develops in a fine-tuned and very complex microenvironment. Immune cell composition and interactions with tumor as well as stromal cells play a crucial role in development and progression of liver cancer. Modern immune-oncological approaches in HCC significantly expanded the landscape of active compounds in HCC over the recent years. However, efficacy of targeting individual aspects of immune response, including checkpoint molecules, remain decisively low. Furthermore, predictive biomarkers for therapy response are still largely missing. Thus, implementation of results and different approaches from preclinical, translational studies might be of utmost importance to identify novel cellular or molecular targets that synergistically could improve currently used strategies. Herein, an improved understanding of the landscape of immune-oncological alterations and rationale for subsequent molecularly-guided combination therapies are urgently needed. Up till now, our current understanding remains incomplete and precise dissection of intra- and inter-tumoral heterogeneity using single cell sequencing approaches still is in its infancy for HCC. In addition, detailed knowledge on the immune-cell contexture will add additional layers of complexity that requires detailed preclinical models that closely resemble authentic human HCC. However, a better understanding of molecular interaction and pathways on a cellular level is imperative to develop new treatment regimens or combination of regimes. As the knowledge on molecular and immune-modulatory pathways evolve, the corresponding context of application and genetic background will need to be tightly controlled to ultimately implement the translational finding, overcome therapy resistance, and increase clinical response rates. Nevertheless, recent findings form clinical trials on different combination therapies are highly promising and will likely further shape the therapeutic landscape and enter the clinical practice of HCC treatment.

Author Contributions: S.H. and D.C. contributed equally to the literature research and writing of the manuscript. Figures were generated by S.H., and P.R.G. and J.U.M. designed and supervised the research process and the manuscript preparation. All authors have read and agreed to the published version of the manuscript.

Funding: J.U.M. is supported by grants from the German Research Foundation (MA 4443/2-2; SFB1292), the Volkswagen Foundation (Lichtenberg program), and by a grant from the Wilhelm-Sander Foundation (2017.007.1).

Conflicts of Interest: The authors declare no conflict of interest.

$\begin{array}{ll}\text { Abbreviations } \\ \mathrm{Ab} & \text { Antibody } \\ \mathrm{AFP} & \text { alpha-fetoprotein } \\ \mathrm{APC} & \text { antigen presenting cells } \\ \text { CCRK } & \text { cell cycle-related kinase } \\ \mathrm{CPS} & \text { combined positive score } \\ \text { CSF1 } & \text { colony stimulating factor 1 } \\ \text { CSF1R } & \text { colony stimulating factor receptor 1 } \\ \text { CTLA-4 } & \text { cytotoxic T lymphocyte antigen 4 } \\ \text { CXCR-4 } & \text { CXC receptor type 4 } \\ \text { DC } & \text { dendritic cell } \\ \text { GPC3 } & \text { glypican-3 } \\ \text { HCC } & \text { hepatocellular carcinoma } \\ \text { HSC } & \text { hepatic stellate cell } \\ \text { ICI } & \text { immune checkpoint inhibitor } \\ \text { IDO1 } & \text { indoleamine 2,3-dioxygenase 1 } \\ \text { LAG3 } & \text { lymphocyte activation gene 3 } \\ \text { M-MDSC } & \text { monocytic MDSC } \\ \text { MDSC } & \text { myeloid-derived suppressor cells } \\ \text { NAFLD } & \text { non-alcoholic fatty liver disease } \\ \text { NASH } & \text { non-alcoholic steato hepatitis } \\ & \end{array}$




$\begin{array}{ll}\text { NF- } \kappa \text { B } & \text { nuclear factor- } \kappa \text { B } \\ \text { NK cells } & \text { natural killer cells } \\ \text { NSCLC } & \text { non-small cell lung cancer } \\ \text { OR } & \text { overall response rate } \\ \text { OS } & \text { overall survival } \\ \text { PBMC } & \text { peripheral blood mononuclear cells } \\ \text { PD-1 } & \text { programmed death protein 1 } \\ \text { PD-L1 } & \text { programmed death ligand 1 } \\ \text { PFS } & \text { progression free survival } \\ \text { PSC } & \text { primary sclerosing cholangitis } \\ \text { TAM } & \text { tumor-associated macrophages } \\ \text { Th } & \text { T helper } \\ \text { TIL } & \text { tumor infiltrating lymphocytes } \\ \text { TIM3 } & \text { T cell membrane protein 3 } \\ \text { TKI } & \text { tyrosine kinase inhibitor } \\ \text { TME } & \text { tumor microenvironment } \\ \text { TPS } & \text { tumor proportion score } \\ \text { Treg } & \text { regulatory T cells } \\ \text { VEGF } & \text { vascular endothelial growth factor }\end{array}$

\section{References}

1. Khan, S.A.; Taylor-Robinson, S.D.; Toledano, M.B.; Beck, A.; Elliott, P.; Thomas, H.C. Changing international trends in mortality rates for liver, biliary and pancreatic tumours. J. Hepatol. 2002, 37, 806-813. [CrossRef]

2. Saha, S.K.; Zhu, A.X.; Fuchs, C.S.; Brooks, G.A. Forty-Year Trends in Cholangiocarcinoma Incidence in the U.S.: Intrahepatic Disease on the Rise. Oncologist 2016, 21, 594-599. [CrossRef]

3. Ryerson, A.B.; Eheman, C.R.; Altekruse, S.F.; Ward, J.W.; Jemal, A.; Sherman, R.L.; Henley, S.J.; Holtzman, D.; Lake, A.; Noone, A.M.; et al. Annual Report to the Nation on the Status of Cancer, 1975-2012, featuring the increasing incidence of liver cancer. Cancer 2016, 122, 1312-1337. [CrossRef]

4. Bray, F.; Ferlay, J.; Soerjomataram, I.; Siegel, R.L.; Torre, L.A.; Jemal, A. Global cancer statistics 2018: GLOBOCAN estimates of incidence and mortality worldwide for 36 cancers in 185 countries. CA Cancer J. Clin. 2018, 68, 394-424. [CrossRef]

5. Budhu, A.; Wang, X.W. The role of cytokines in hepatocellular carcinoma. J. Leukoc. Biol. 2006, 80, 1197-1213. [CrossRef]

6. Liu, Z.; Jiang, Y.; Yuan, H.; Fang, Q.; Cai, N.; Suo, C.; Jin, L.; Zhang, T.; Chen, X. The trends in incidence of primary liver cancer caused by specific etiologies: Results from the Global Burden of Disease Study 2016 and implications for liver cancer prevention. J. Hepatol. 2019, 70, 674-683. [CrossRef]

7. Sun, B.; Karin, M. Obesity, inflammation, and liver cancer. J. Hepatol. 2012, 56, 704-713. [CrossRef]

8. Michelotti, G.A.; Machado, M.V.; Diehl, A.M. NAFLD, NASH and liver cancer. Nat. Rev. Gastroenterol. Hepatol. 2013, 10, 656-665. [CrossRef]

9. Greten, T.F.; Wang, X.W.; Korangy, F. Current concepts of immune based treatments for patients with HCC: From basic science to novel treatment approaches. Gut 2015, 64, 842-848. [CrossRef]

10. Ambade, A.; Satishchandran, A.; Saha, B.; Gyongyosi, B.; Lowe, P.; Kodys, K.; Catalano, D.; Szabo, G. Hepatocellular carcinoma is accelerated by NASH involving M2 macrophage polarization mediated by hif-1 $\alpha$ induced IL-10. Oncoimmunology 2016, 5, e1221557. [CrossRef]

11. Galle, P.R.; Tovoli, F.; Foerster, F.; Worns, M.A.; Cucchetti, A.; Bolondi, L. The treatment of intermediate stage tumours beyond TACE: From surgery to systemic therapy. J. Hepatol. 2017. [CrossRef] [PubMed]

12. Duffy, A.G.; Greten, T.F. Liver cancer: Regorafenib as second-line therapy in hepatocellular carcinoma. Nat. Rev. Gastroenterol. Hepatol. 2017, 14, 141-142. [CrossRef] [PubMed]

13. Bruix, J.; Qin, S.; Merle, P.; Granito, A.; Huang, Y.H.; Bodoky, G.; Pracht, M.; Yokosuka, O.; Rosmorduc, O.; Breder, V.; et al. Regorafenib for patients with hepatocellular carcinoma who progressed on sorafenib treatment (RESORCE): A randomised, double-blind, placebo-controlled, phase 3 trial. Lancet 2017, 389, 56-66. [CrossRef] 
14. Llovet, J.M.; Ricci, S.; Mazzaferro, V.; Hilgard, P.; Gane, E.; Blanc, J.F.; de Oliveira, A.C.; Santoro, A.; Raoul, J.L.; Forner, A.; et al. Sorafenib in advanced hepatocellular carcinoma. N. Engl. J. Med. 2008, 359, 378-390. [CrossRef] [PubMed]

15. Kudo, M.; Finn, R.S.; Qin, S.; Han, K.H.; Ikeda, K.; Piscaglia, F.; Baron, A.; Park, J.W.; Han, G.; Jassem, J.; et al. Lenvatinib versus sorafenib in first-line treatment of patients with unresectable hepatocellular carcinoma: A randomised phase 3 non-inferiority trial. Lancet 2018, 391, 1163-1173. [CrossRef]

16. Abou-Alfa, G.K.; Meyer, T.; Cheng, A.L.; El-Khoueiry, A.B.; Rimassa, L.; Ryoo, B.Y.; Cicin, I.; Merle, P.; Chen, Y.; Park, J.W.; et al. Cabozantinib in Patients with Advanced and Progressing Hepatocellular Carcinoma. N. Engl. J. Med. 2018, 379, 54-63. [CrossRef]

17. Zhu, A.X.; Kang, Y.K.; Yen, C.J.; Finn, R.S.; Galle, P.R.; Llovet, J.M.; Assenat, E.; Brandi, G.; Pracht, M.; Lim, H.Y.; et al. Ramucirumab after sorafenib in patients with advanced hepatocellular carcinoma and increased $\alpha$-fetoprotein concentrations (REACH-2): A randomised, double-blind, placebo-controlled, phase 3 trial. Lancet. Oncol. 2019, 20, 282-296. [CrossRef]

18. Pinyol, R.; Sia, D.; Llovet, J.M. Immune Exclusion-Wnt/CTNNB1 Class Predicts Resistance to Immunotherapies in HCC. Clin. Cancer Res. Off. J. Am. Assoc. Cancer Res. 2019, 25, 2021-2023. [CrossRef]

19. Yin, C.; Evason, K.J.; Asahina, K.; Stainier, D.Y. Hepatic stellate cells in liver development, regeneration, and cancer. J. Clin. Investig. 2013, 123, 1902-1910. [CrossRef]

20. Jenne, C.N.; Kubes, P. Immune surveillance by the liver. Nat. Immunol. 2013, 14, 996-1006. [CrossRef]

21. Makarova-Rusher, O.V.; Medina-Echeverz, J.; Duffy, A.G.; Greten, T.F. The yin and yang of evasion and immune activation in HCC. J. Hepatol. 2015, 62, 1420-1429. [CrossRef] [PubMed]

22. Zheng, C.; Zheng, L.; Yoo, J.K.; Guo, H.; Zhang, Y.; Guo, X.; Kang, B.; Hu, R.; Huang, J.Y.; Zhang, Q.; et al. Landscape of Infiltrating T Cells in Liver Cancer Revealed by Single-Cell Sequencing. Cell 2017, 169, 1342-1356.e16. [CrossRef] [PubMed]

23. Kapanadze, T.; Gamrekelashvili, J.; Ma, C.; Chan, C.; Zhao, F.; Hewitt, S.; Zender, L.; Kapoor, V.; Felsher, D.W.; Manns, M.P.; et al. Regulation of accumulation and function of myeloid derived suppressor cells in different murine models of hepatocellular carcinoma. J. Hepatol. 2013, 59, 1007-1013. [CrossRef] [PubMed]

24. Mizukoshi, E.; Yamashita, T.; Arai, K.; Terashima, T.; Kitahara, M.; Nakagawa, H.; Iida, N.; Fushimi, K.; Kaneko, S. Myeloid-derived suppressor cells correlate with patient outcomes in hepatic arterial infusion chemotherapy for hepatocellular carcinoma. Cancer Immunol. Immunother. 2016, 65, 715-725. [CrossRef] [PubMed]

25. Yang, X.H.; Yamagiwa, S.; Ichida, T.; Matsuda, Y.; Sugahara, S.; Watanabe, H.; Sato, Y.; Abo, T.; Horwitz, D.A.; Aoyagi, Y. Increase of CD4+ CD25+ regulatory T-cells in the liver of patients with hepatocellular carcinoma. J. Hepatol. 2006, 45, 254-262. [CrossRef]

26. Iwata, T.; Kondo, Y.; Kimura, O.; Morosawa, T.; Fujisaka, Y.; Umetsu, T.; Kogure, T.; Inoue, J.; Nakagome, Y.; Shimosegawa, T. PD-L1(+)MDSCs are increased in HCC patients and induced by soluble factor in the tumor microenvironment. Sci. Rep. 2016, 6, 39296. [CrossRef]

27. Foerster, F.; Hess, M.; Gerhold-Ay, A.; Marquardt, J.U.; Becker, D.; Galle, P.R.; Schuppan, D.; Binder, H.; Bockamp, E. The immune contexture of hepatocellular carcinoma predicts clinical outcome. Sci. Rep. 2018, 8 , 5351. [CrossRef]

28. Brunner, S.M.; Rubner, C.; Kesselring, R.; Martin, M.; Griesshammer, E.; Ruemmele, P.; Stempfl, T.; Teufel, A.; Schlitt, H.J.; Fichtner-Feigl, S. Tumor-infiltrating, interleukin-33-producing effector-memory CD8(+) T cells in resected hepatocellular carcinoma prolong patient survival. Hepatology 2015, 61, 1957-1967. [CrossRef]

29. Li, H.; Han, Y.; Guo, Q.; Zhang, M.; Cao, X. Cancer-expanded myeloid-derived suppressor cells induce anergy of NK cells through membrane-bound TGF-beta 1. J. Immunol. 2009, 182, 240-249. [CrossRef] [PubMed]

30. Prieto, J.; Melero, I.; Sangro, B. Immunological landscape and immunotherapy of hepatocellular carcinoma. Nat. Rev. Gastroenterol. Hepatol. 2015, 12, 681-700. [CrossRef]

31. Schreiber, R.D.; Old, L.J.; Smyth, M.J. Cancer immunoediting: Integrating immunity's roles in cancer suppression and promotion. Science 2011, 331, 1565-1570. [CrossRef] [PubMed]

32. Yu, L.X.; Ling, Y.; Wang, H.Y. Role of nonresolving inflammation in hepatocellular carcinoma development and progression. NPJ Precis. Oncol. 2018, 2, 6. [CrossRef] [PubMed]

33. Eggert, T.; Wolter, K.; Ji, J.; Ma, C.; Yevsa, T.; Klotz, S.; Medina-Echeverz, J.; Longerich, T.; Forgues, M.; Reisinger, F; et al. Distinct Functions of Senescence-Associated Immune Responses in Liver Tumor Surveillance and Tumor Progression. Cancer Cell 2016, 30, 533-547. [CrossRef] [PubMed] 
34. Sprinzl, M.F.; Reisinger, F.; Puschnik, A.; Ringelhan, M.; Ackermann, K.; Hartmann, D.; Schiemann, M.; Weinmann, A.; Galle, P.R.; Schuchmann, M.; et al. Sorafenib perpetuates cellular anticancer effector functions by modulating the crosstalk between macrophages and natural killer cells. Hepatology 2013, 57, 2358-2368. [CrossRef]

35. Ma, C.; Kesarwala, A.H.; Eggert, T.; Medina-Echeverz, J.; Kleiner, D.E.; Jin, P.; Stroncek, D.F.; Terabe, M.; Kapoor, V.; ElGindi, M.; et al. NAFLD causes selective CD4(+) T lymphocyte loss and promotes hepatocarcinogenesis. Nature 2016, 531, 253-257. [CrossRef]

36. Wu, Y.; Kuang, D.M.; Pan, W.D.; Wan, Y.L.; Lao, X.M.; Wang, D.; Li, X.F.; Zheng, L. Monocyte/macrophageelicited natural killer cell dysfunction in hepatocellular carcinoma is mediated by CD48/2B4 interactions. Hepatology 2013, 57, 1107-1116. [CrossRef]

37. Sui, Q.; Zhang, J.; Sun, X.; Zhang, C.; Han, Q.; Tian, Z. NK cells are the crucial antitumor mediators when STAT3-mediated immunosuppression is blocked in hepatocellular carcinoma. J. Immunol. 2014, 193, 2016-2023. [CrossRef]

38. Zhou, J.; Ding, T.; Pan, W.; Zhu, L.Y.; Li, L.; Zheng, L. Increased intratumoral regulatory T cells are related to intratumoral macrophages and poor prognosis in hepatocellular carcinoma patients. Int. J. Cancer 2009, 125, 1640-1648. [CrossRef]

39. Dong, P.; Ma, L.; Liu, L.; Zhao, G.; Zhang, S.; Dong, L.; Xue, R.; Chen, S. CD86 ${ }^{+} / C_{2} 206^{+}$, Diametrically Polarized Tumor-Associated Macrophages, Predict Hepatocellular Carcinoma Patient Prognosis. Int. J. Mol. Sci. 2016, 17, 320. [CrossRef] [PubMed]

40. El-Khoueiry, A.B.; Sangro, B.; Yau, T.; Crocenzi, T.S.; Kudo, M.; Hsu, C.; Kim, T.Y.; Choo, S.P.; Trojan, J.; Welling, T.H.R.; et al. Nivolumab in patients with advanced hepatocellular carcinoma (CheckMate 040): An open-label, non-comparative, phase 1/2 dose escalation and expansion trial. Lancet 2017, 389, 2492-2502. [CrossRef]

41. Zhu, A.X.; Finn, R.S.; Edeline, J.; Cattan, S.; Ogasawara, S.; Palmer, D.; Verslype, C.; Zagonel, V.; Fartoux, L.; Vogel, A.; et al. Pembrolizumab in patients with advanced hepatocellular carcinoma previously treated with sorafenib (KEYNOTE-224): A non-randomised, open-label phase 2 trial. Lancet. Oncol. 2018, 19, 940-952. [CrossRef]

42. Yau, T.; Kang, Y.-K.; Kim, T.-Y.; El-Khoueiry, A.B.; Santoro, A.; Sangro, B.; Melero, I.; Kudo, M.; Hou, M.-M.; Matilla, A.; et al. Nivolumab (NIVO) + ipilimumab (IPI) combination therapy in patients (pts) with advanced hepatocellular carcinoma (aHCC): Results from CheckMate 040. J. Clin. Oncol. 2019, 37, 4012. [CrossRef]

43. Duffy, A.G.; Ulahannan, S.V.; Makorova-Rusher, O.; Rahma, O.; Wedemeyer, H.; Pratt, D.; Davis, J.L.; Hughes, M.S.; Heller, T.; ElGindi, M.; et al. Tremelimumab in combination with ablation in patients with advanced hepatocellular carcinoma. J. Hepatol. 2017, 66, 545-551. [CrossRef] [PubMed]

44. Sangro, B.; Gomez-Martin, C.; de la Mata, M.; Inarrairaegui, M.; Garralda, E.; Barrera, P.; Riezu-Boj, J.I.; Larrea, E.; Alfaro, C.; Sarobe, P.; et al. A clinical trial of CTLA-4 blockade with tremelimumab in patients with hepatocellular carcinoma and chronic hepatitis C. J. Hepatol. 2013, 59, 81-88. [CrossRef]

45. Abou-Alfa, G.K.; Chan, S.L.; Furuse, J.; Galle, P.R.; Kelley, R.K.; Qin, S.; Armstrong, J.; Darilay, A.; Vlahovic, G.; Negro, A.; et al. A randomized, multicenter phase 3 study of durvalumab (D) and tremelimumab (T) as first-line treatment in patients with unresectable hepatocellular carcinoma (HCC): HIMALAYA study. J. Clin. Oncol. 2018, 36, TPS4144. [CrossRef]

46. Kelley, R.K.; Sangro, B.; Harris, W.P.; Ikeda, M.; Okusaka, T.; Kang, Y.-K.; Qin, S.; Tai, W.M.D.; Lim, H.Y.; Yau, T.; et al. Efficacy, tolerability, and biologic activity of a novel regimen of tremelimumab (T) in combination with durvalumab (D) for patients (pts) with advanced hepatocellular carcinoma (aHCC). J. Clin. Oncol. 2020, 38, 4508. [CrossRef]

47. Yau, T.; Zagonel, V.; Santoro, A.; Acosta-Rivera, M.; Choo, S.P.; Matilla, A.; He, A.R.; Gracián, A.C.; El-Khoueiry, A.B.; Sangro, B.; et al. Nivolumab (NIVO) + ipilimumab (IPI) + cabozantinib (CABO) combination therapy in patients (pts) with advanced hepatocellular carcinoma (aHCC): Results from CheckMate 040. J. Clin. Oncol. 2020, 38, 478. [CrossRef]

48. Finn, R.S.; Qin, S.; Ikeda, M.; Galle, P.R.; Ducreux, M.; Kim, T.Y.; Kudo, M.; Breder, V.; Merle, P.; Kaseb, A.O.; et al. Atezolizumab plus Bevacizumab in Unresectable Hepatocellular Carcinoma. N. Engl. J. Med. 2020, 382, 1894-1905. [CrossRef]

49. Brown, Z.J.; Greten, T.F.; Heinrich, B. Adjuvant Treatment of Hepatocellular Carcinoma: Prospect of Immunotherapy. Hepatology 2019, 70, 1437-1442. [CrossRef] 
50. Adcock, C.S.; Puneky, L.V.; Campbell, G.S. Favorable Response of Metastatic Hepatocellular Carcinoma to Treatment with Trans-arterial Radioembolization Followed by Sorafenib and Nivolumab. Cureus 2019, 11, e4083. [CrossRef]

51. Crispe, I.N. The liver as a lymphoid organ. Annu. Rev. Immunol. 2009, 27, 147-163. [CrossRef] [PubMed]

52. Schumacher, T.N.; Schreiber, R.D. Neoantigens in cancer immunotherapy. Science 2015, 348, 69-74. [CrossRef] [PubMed]

53. Bernstein, M.B.; Krishnan, S.; Hodge, J.W.; Chang, J.Y. Immunotherapy and stereotactic ablative radiotherapy (ISABR): A curative approach? Nat. Rev. Clin. Oncol. 2016, 13, 516-524. [CrossRef] [PubMed]

54. Mizukoshi, E.; Yamashita, T.; Arai, K.; Sunagozaka, H.; Ueda, T.; Arihara, F.; Kagaya, T.; Yamashita, T.; Fushimi, K.; Kaneko, S. Enhancement of tumor-associated antigen-specific T cell responses by radiofrequency ablation of hepatocellular carcinoma. Hepatology 2013, 57, 1448-1457. [CrossRef]

55. Zhang, Q.; Zhang, Z.; Peng, M.; Fu, S.; Xue, Z.; Zhang, R. CAR-T cell therapy in gastrointestinal tumors and hepatic carcinoma: From bench to bedside. Oncoimmunology 2016, 5, e1251539. [CrossRef]

56. Lee, J.H.; Lee, J.H.; Lim, Y.S.; Yeon, J.E.; Song, T.J.; Yu, S.J.; Gwak, G.Y.; Kim, K.M.; Kim, Y.J.; Lee, J.W.; et al. Adjuvant immunotherapy with autologous cytokine-induced killer cells for hepatocellular carcinoma. Gastroenterology 2015, 148, 1383-1391.e16. [CrossRef]

57. Zou, W. Immunosuppressive networks in the tumour environment and their therapeutic relevance. Nat. Rev. Cancer 2005, 5, 263-274. [CrossRef]

58. Hogdall, D.; Lewinska, M.; Andersen, J.B. Desmoplastic Tumor Microenvironment and Immunotherapy in Cholangiocarcinoma. Trends Cancer 2018, 4, 239-255. [CrossRef]

59. Topalian, S.L.; Hodi, F.S.; Brahmer, J.R.; Gettinger, S.N.; Smith, D.C.; McDermott, D.F.; Powderly, J.D.; Carvajal, R.D.; Sosman, J.A.; Atkins, M.B.; et al. Safety, activity, and immune correlates of anti-PD-1 antibody in cancer. N. Engl. J. Med. 2012, 366, 2443-2454. [CrossRef]

60. Tumeh, P.C.; Harview, C.L.; Yearley, J.H.; Shintaku, I.P.; Taylor, E.J.; Robert, L.; Chmielowski, B.; Spasic, M.; Henry, G.; Ciobanu, V.; et al. PD-1 blockade induces responses by inhibiting adaptive immune resistance. Nature 2014, 515, 568-571. [CrossRef]

61. Brown, Z.J.; Heinrich, B.; Greten, T.F. Mouse models of hepatocellular carcinoma: An overview and highlights for immunotherapy research. Nat. Rev. Gastroenterol. Hepatol. 2018, 15, 536-554. [CrossRef] [PubMed]

62. Schachter, J.; Ribas, A.; Long, G.V.; Arance, A.; Grob, J.J.; Mortier, L.; Daud, A.; Carlino, M.S.; McNeil, C.; Lotem, M.; et al. Pembrolizumab versus ipilimumab for advanced melanoma: Final overall survival results of a multicentre, randomised, open-label phase 3 study (KEYNOTE-006). Lancet 2017, 390, 1853-1862. [CrossRef]

63. Gandhi, L.; Rodríguez-Abreu, D.; Gadgeel, S.; Esteban, E.; Felip, E.; De Angelis, F.; Domine, M.; Clingan, P.; Hochmair, M.J.; Powell, S.F.; et al. Pembrolizumab plus Chemotherapy in Metastatic Non-Small-Cell Lung Cancer. N. Engl. J. Med. 2018, 378, 2078-2092. [CrossRef] [PubMed]

64. Brahmer, J.; Reckamp, K.L.; Baas, P.; Crinò, L.; Eberhardt, W.E.; Poddubskaya, E.; Antonia, S.; Pluzanski, A.; Vokes, E.E.; Holgado, E.; et al. Nivolumab versus Docetaxel in Advanced Squamous-Cell Non-Small-Cell Lung Cancer. N. Engl. J. Med. 2015, 373, 123-135. [CrossRef] [PubMed]

65. Larkin, J.; Chiarion-Sileni, V.; Gonzalez, R.; Grob, J.J.; Cowey, C.L.; Lao, C.D.; Schadendorf, D.; Dummer, R.; Smylie, M.; Rutkowski, P.; et al. Combined Nivolumab and Ipilimumab or Monotherapy in Untreated Melanoma. N. Engl. J. Med. 2015, 373, 23-34. [CrossRef] [PubMed]

66. Le, D.T.; Durham, J.N.; Smith, K.N.; Wang, H.; Bartlett, B.R.; Aulakh, L.K.; Lu, S.; Kemberling, H.; Wilt, C.; Luber, B.S.; et al. Mismatch repair deficiency predicts response of solid tumors to PD-1 blockade. Science 2017, 357, 409-413. [CrossRef] [PubMed]

67. Xie, C.; Duffy, A.G.; Mabry-Hrones, D.; Wood, B.; Levy, E.; Krishnasamy, V.; Khan, J.; Wei, J.S.; Agdashian, D.; Tyagi, M.; et al. Tremelimumab in Combination With Microwave Ablation in Patients With Refractory Biliary Tract Cancer. Hepatology 2019, 69, 2048-2060. [CrossRef]

68. Gou, M.; Zhang, Y.; Si, H.; Dai, G. Efficacy and safety of nivolumab for metastatic biliary tract cancer. Onco Targets Ther. 2019, 12, 861-867. [CrossRef]

69. Kim, R.D.; Kim, D.W.; Alese, O.B.; Li, D.; Shah, N.; Schell, M.J.; Zhou, J.M.; Chung, V. A phase II study of nivolumab in patients with advanced refractory biliary tract cancers (BTC). J. Clin. Oncol. 2019, 37, 4097. [CrossRef] 
70. Finn, R.S.; Ryoo, B.-Y.; Merle, P.; Kudo, M.; Bouattour, M.; Lim, H.-Y.; Breder, V.V.; Edeline, J.; Chao, Y.; Ogasawara, S.; et al. Results of KEYNOTE-240: Phase 3 study of pembrolizumab (Pembro) vs best supportive care (BSC) for second line therapy in advanced hepatocellular carcinoma (HCC). Am. Soc. Clin. Oncol. 2019, 37, 4004. [CrossRef]

71. Li, G.; Liu, D.; Cooper, T.K.; Kimchi, E.T.; Qi, X.; Avella, D.M.; Li, N.; Yang, Q.X.; Kester, M.; Rountree, C.B.; et al. Successful chemoimmunotherapy against hepatocellular cancer in a novel murine model. J. Hepatol. 2017, 66, 75-85. [CrossRef] [PubMed]

72. Friedman, D.; Baird, J.R.; Young, K.H.; Cottam, B.; Crittenden, M.R.; Friedman, S.; Gough, M.J.; Newell, P. Programmed cell death-1 blockade enhances response to stereotactic radiation in an orthotopic murine model of hepatocellular carcinoma. Hepatol. Res. Off. J. Jpn. Soc. Hepatol. 2017, 47, 702-714. [CrossRef] [PubMed]

73. Yau, T.; Park, J.W.; Finn, R.S.; Cheng, A.-L.; Mathurin, P.; Edeline, J.; Kudo, M.; Han, K.-H.; Harding, J.J.; Merle, P.; et al. LBA38_PRCheckMate 459: A randomized, multi-center phase III study of nivolumab (NIVO) vs sorafenib (SOR) as first-line (1L) treatment in patients (pts) with advanced hepatocellular carcinoma (aHCC). Ann. Oncol. 2019, 30. [CrossRef]

74. Champiat, S.; Ferrara, R.; Massard, C.; Besse, B.; Marabelle, A.; Soria, J.C.; Ferte, C. Hyperprogressive disease: Recognizing a novel pattern to improve patient management. Nat. Rev. Clin. Oncol. 2018, 15, 748-762. [CrossRef]

75. Kim, H.D.; Song, G.W.; Park, S.; Jung, M.K.; Kim, M.H.; Kang, H.J.; Yoo, C.; Yi, K.; Kim, K.H.; Eo, S.; et al. Association Between Expression Level of PD1 by Tumor-Infiltrating CD8(+) T Cells and Features of Hepatocellular Carcinoma. Gastroenterology 2018, 155, 1936-1950.e17. [CrossRef]

76. Calderaro, J.; Rousseau, B.; Amaddeo, G.; Mercey, M.; Charpy, C.; Costentin, C.; Luciani, A.; Zafrani, E.S.; Laurent, A.; Azoulay, D.; et al. Programmed death ligand 1 expression in hepatocellular carcinoma: Relationship With clinical and pathological features. Hepatology 2016, 64, 2038-2046. [CrossRef]

77. Zhao, P.; Li, L.; Jiang, X.; Li, Q. Mismatch repair deficiency/microsatellite instability-high as a predictor for anti-PD-1/PD-L1 immunotherapy efficacy. J. Hematol. Oncol. 2019, 12, 54. [CrossRef]

78. Gao, Q.; Wang, X.Y.; Qiu, S.J.; Yamato, I.; Sho, M.; Nakajima, Y.; Zhou, J.; Li, B.Z.; Shi, Y.H.; Xiao, Y.S.; et al. Overexpression of PD-L1 significantly associates with tumor aggressiveness and postoperative recurrence in human hepatocellular carcinoma. Clin. Cancer Res. Off. J. Am. Assoc. Cancer Res. 2009, 15, 971-979. [CrossRef]

79. Thommen, D.S.; Koelzer, V.H.; Herzig, P.; Roller, A.; Trefny, M.; Dimeloe, S.; Kiialainen, A.; Hanhart, J.; Schill, C.; Hess, C.; et al. A transcriptionally and functionally distinct PD-1(+) CD8(+) T cell pool with predictive potential in non-small-cell lung cancer treated with PD-1 blockade. Nat. Med. 2018, 24, 994-1004. [CrossRef]

80. Wang, B.J.; Bao, J.J.; Wang, J.Z.; Wang, Y.; Jiang, M.; Xing, M.Y.; Zhang, W.G.; Qi, J.Y.; Roggendorf, M.; Lu, M.J.; et al. Immunostaining of PD-1/PD-Ls in liver tissues of patients with hepatitis and hepatocellular carcinoma. World J. Gastroenterol. 2011, 17, 3322-3329. [CrossRef]

81. Shi, F.; Shi, M.; Zeng, Z.; Qi, R.Z.; Liu, Z.W.; Zhang, J.Y.; Yang, Y.P.; Tien, P.; Wang, F.S. PD-1 and PD-L1 upregulation promotes CD8(+) T-cell apoptosis and postoperative recurrence in hepatocellular carcinoma patients. Int. J. Cancer 2011, 128, 887-896. [CrossRef] [PubMed]

82. Zhou, G.; Sprengers, D.; Boor, P.P.C.; Doukas, M.; Schutz, H.; Mancham, S.; Pedroza-Gonzalez, A.; Polak, W.G.; de Jonge, J.; Gaspersz, M.; et al. Antibodies Against Immune Checkpoint Molecules Restore Functions of Tumor-Infiltrating T Cells in Hepatocellular Carcinomas. Gastroenterology 2017, 153, 1107-1119.e10. [CrossRef] [PubMed]

83. Losic, B.; Craig, A.J.; Villacorta-Martin, C.; Martins-Filho, S.N.; Akers, N.; Chen, X.; Ahsen, M.E.; von Felden, J.; Labgaa, I.; D'Avola, D.; et al. Intratumoral heterogeneity and clonal evolution in liver cancer. Nat. Commun. 2020, 11, 291. [CrossRef] [PubMed]

84. Krieg, C.; Nowicka, M.; Guglietta, S.; Schindler, S.; Hartmann, F.J.; Weber, L.M.; Dummer, R.; Robinson, M.D.; Levesque, M.P.; Becher, B. High-dimensional single-cell analysis predicts response to anti-PD-1 immunotherapy. Nat. Med. 2018, 24, 144-153. [CrossRef]

85. Zhang, Q.; He, Y.; Luo, N.; Patel, S.J.; Han, Y.; Gao, R.; Modak, M.; Carotta, S.; Haslinger, C.; Kind, D.; et al. Landscape and Dynamics of Single Immune Cells in Hepatocellular Carcinoma. Cell 2019, 179, 829-845.e20. [CrossRef] 
86. Ma, L.; Hernandez, M.O.; Zhao, Y.; Mehta, M.; Tran, B.; Kelly, M.; Rae, Z.; Hernandez, J.M.; Davis, J.L.; Martin, S.P.; et al. Tumor Cell Biodiversity Drives Microenvironmental Reprogramming in Liver Cancer. Cancer Cell 2019, 36, 418-430.e6. [CrossRef]

87. Kulangara, K.; Zhang, N.; Corigliano, E.; Guerrero, L.; Waldroup, S.; Jaiswal, D.; Ms, M.J.; Shah, S.; Hanks, D.; Wang, J.; et al. Clinical Utility of the Combined Positive Score for Programmed Death Ligand-1 Expression and the Approval of Pembrolizumab for Treatment of Gastric Cancer. Arch. Pathol. Lab. Med. 2019, 143, 330-337. [CrossRef]

88. Garon, E.B.; Rizvi, N.A.; Hui, R.; Leighl, N.; Balmanoukian, A.S.; Eder, J.P.; Patnaik, A.; Aggarwal, C.; Gubens, M.; Horn, L.; et al. Pembrolizumab for the treatment of non-small-cell lung cancer. N. Engl. J. Med. 2015, 372, 2018-2028. [CrossRef]

89. Taube, J.M.; Klein, A.; Brahmer, J.R.; Xu, H.; Pan, X.; Kim, J.H.; Chen, L.; Pardoll, D.M.; Topalian, S.L.; Anders, R.A. Association of PD-1, PD-1 ligands, and other features of the tumor immune microenvironment with response to anti-PD-1 therapy. Clin. Cancer Res. Off. J. Am. Assoc. Cancer Res. 2014, 20, 5064-5074. [CrossRef]

90. Herbst, R.S.; Soria, J.C.; Kowanetz, M.; Fine, G.D.; Hamid, O.; Gordon, M.S.; Sosman, J.A.; McDermott, D.F.; Powderly, J.D.; Gettinger, S.N.; et al. Predictive correlates of response to the anti-PD-L1 antibody MPDL3280A in cancer patients. Nature 2014, 515, 563-567. [CrossRef]

91. Daud, A.I.; Wolchok, J.D.; Robert, C.; Hwu, W.J.; Weber, J.S.; Ribas, A.; Hodi, F.S.; Joshua, A.M.; Kefford, R.; Hersey, P.; et al. Programmed Death-Ligand 1 Expression and Response to the Anti-Programmed Death 1 Antibody Pembrolizumab in Melanoma. J. Clin. Oncol. Off. J. Am. Soc. Clin. Oncol. 2016, 34, 4102-4109. [CrossRef] [PubMed]

92. Udall, M.; Rizzo, M.; Kenny, J.; Doherty, J.; Dahm, S.; Robbins, P.; Faulkner, E. PD-L1 diagnostic tests: A systematic literature review of scoring algorithms and test-validation metrics. Diagn. Pathol. 2018, 13, 12. [CrossRef] [PubMed]

93. Pinato, D.J.; Guerra, N.; Fessas, P.; Murphy, R.; Mineo, T.; Mauri, F.A.; Mukherjee, S.K.; Thursz, M.; Wong, C.N.; Sharma, R.; et al. Immune-based therapies for hepatocellular carcinoma. Oncogene 2020, 39, 3620-3637. [CrossRef] [PubMed]

94. Cristescu, R.; Mogg, R.; Ayers, M.; Albright, A.; Murphy, E.; Yearley, J.; Sher, X.; Liu, X.Q.; Lu, H.; Nebozhyn, M.; et al. Pan-tumor genomic biomarkers for PD-1 checkpoint blockade-based immunotherapy. Science 2018, 362. [CrossRef] [PubMed]

95. Le, D.T.; Uram, J.N.; Wang, H.; Bartlett, B.R.; Kemberling, H.; Eyring, A.D.; Skora, A.D.; Luber, B.S.; Azad, N.S.; Laheru, D.; et al. PD-1 Blockade in Tumors with Mismatch-Repair Deficiency. N. Engl. J. Med. 2015, 372, 2509-2520. [CrossRef]

96. Yarchoan, M.; Hopkins, A.; Jaffee, E.M. Tumor Mutational Burden and Response Rate to PD-1 Inhibition. N. Engl. J. Med. 2017, 377, 2500-2501. [CrossRef]

97. Ang, C.; Klempner, S.J.; Ali, S.M.; Madison, R.; Ross, J.S.; Severson, E.A.; Fabrizio, D.; Goodman, A.; Kurzrock, R.; Suh, J.; et al. Prevalence of established and emerging biomarkers of immune checkpoint inhibitor response in advanced hepatocellular carcinoma. Oncotarget 2019, 10, 4018-4025. [CrossRef]

98. Goumard, C.; Desbois-Mouthon, C.; Wendum, D.; Calmel, C.; Merabtene, F.; Scatton, O.; Praz, F. Low Levels of Microsatellite Instability at Simple Repeated Sequences Commonly Occur in Human Hepatocellular Carcinoma. Cancer Genom. Proteom. 2017, 14, 329-339. [CrossRef]

99. Totoki, Y.; Tatsuno, K.; Covington, K.R.; Ueda, H.; Creighton, C.J.; Kato, M.; Tsuji, S.; Donehower, L.A.; Slagle, B.L.; Nakamura, H.; et al. Trans-ancestry mutational landscape of hepatocellular carcinoma genomes. Nat. Genet. 2014, 46, 1267-1273. [CrossRef]

100. Agdashian, D.; ElGindi, M.; Xie, C.; Sandhu, M.; Pratt, D.; Kleiner, D.E.; Figg, W.D.; Rytlewski, J.A.; Sanders, C.; Yusko, E.C.; et al. The effect of anti-CTLA4 treatment on peripheral and intra-tumoral T cells in patients with hepatocellular carcinoma. Cancer Immunol. Immunother. 2019, 68, 599-608. [CrossRef]

101. Finkelmeier, F.; Canli, O.; Tal, A.; Pleli, T.; Trojan, J.; Schmidt, M.; Kronenberger, B.; Zeuzem, S.; Piiper, A.; Greten, F.R.; et al. High levels of the soluble programmed death-ligand (sPD-L1) identify hepatocellular carcinoma patients with a poor prognosis. Eur. J. Cancer 2016, 59, 152-159. [CrossRef] [PubMed] 
102. Feun, L.G.; Li, Y.Y.; Wu, C.; Wangpaichitr, M.; Jones, P.D.; Richman, S.P.; Madrazo, B.; Kwon, D.; Garcia-Buitrago, M.; Martin, P.; et al. Phase 2 study of pembrolizumab and circulating biomarkers to predict anticancer response in advanced, unresectable hepatocellular carcinoma. Cancer 2019, 125, 3603-3614. [CrossRef] [PubMed]

103. Zhou, J.; Mahoney, K.M.; Giobbie-Hurder, A.; Zhao, F.; Lee, S.; Liao, X.; Rodig, S.; Li, J.; Wu, X.; Butterfield, L.H.; et al. Soluble PD-L1 as a Biomarker in Malignant Melanoma Treated with Checkpoint Blockade. Cancer Immunol. Res. 2017, 5, 480-492. [CrossRef] [PubMed]

104. Loo, T.M.; Kamachi, F.; Watanabe, Y.; Yoshimoto, S.; Kanda, H.; Arai, Y.; Nakajima-Takagi, Y.; Iwama, A.; Koga, T.; Sugimoto, Y.; et al. Gut Microbiota Promotes Obesity-Associated Liver Cancer through PGE(2)-Mediated Suppression of Antitumor Immunity. Cancer Discov. 2017, 7, 522-538. [CrossRef] [PubMed]

105. Sivan, A.; Corrales, L.; Hubert, N.; Williams, J.B.; Aquino-Michaels, K.; Earley, Z.M.; Benyamin, F.W.; Lei, Y.M.; Jabri, B.; Alegre, M.L.; et al. Commensal Bifidobacterium promotes antitumor immunity and facilitates anti-PD-L1 efficacy. Science 2015, 350, 1084-1089. [CrossRef] [PubMed]

106. Vétizou, M.; Pitt, J.M.; Daillère, R.; Lepage, P.; Waldschmitt, N.; Flament, C.; Rusakiewicz, S.; Routy, B.; Roberti, M.P.; Duong, C.P.; et al. Anticancer immunotherapy by CTLA-4 blockade relies on the gut microbiota. Science 2015, 350, 1079-1084. [CrossRef] [PubMed]

107. Zheng, Y.; Wang, T.; Tu, X.; Huang, Y.; Zhang, H.; Tan, D.; Jiang, W.; Cai, S.; Zhao, P.; Song, R.; et al. Gut microbiome affects the response to anti-PD-1 immunotherapy in patients with hepatocellular carcinoma. J. Immunother Cancer 2019, 7, 193. [CrossRef]

108. Matson, V.; Fessler, J.; Bao, R.; Chongsuwat, T.; Zha, Y.; Alegre, M.L.; Luke, J.J.; Gajewski, T.F. The commensal microbiome is associated with anti-PD-1 efficacy in metastatic melanoma patients. Science 2018, 359, 104-108. [CrossRef]

109. Ma, C.; Han, M.; Heinrich, B.; Fu, Q.; Zhang, Q.; Sandhu, M.; Agdashian, D.; Terabe, M.; Berzofsky, J.A.; Fako, V.; et al. Gut microbiome-mediated bile acid metabolism regulates liver cancer via NKT cells. Science 2018, 360. [CrossRef]

110. Ally, A.; Balasundaram, M.; Carlsen, R.; Chuah, E.; Clarke, A.; Dhalla, N.; Holt, R.A.; Jones, S.J.; Lee, D.; Ma, Y.; et al. Comprehensive and Integrative Genomic Characterization of Hepatocellular Carcinoma. Cell 2017, 169, 1327-1341.e23. [CrossRef]

111. Llovet, J.M.; Montal, R.; Sia, D.; Finn, R.S. Molecular therapies and precision medicine for hepatocellular carcinoma. Nat. Rev. Clin. Oncol. 2018. [CrossRef] [PubMed]

112. Schulze, K.; Imbeaud, S.; Letouzé, E.; Alexandrov, L.B.; Calderaro, J.; Rebouissou, S.; Couchy, G.; Meiller, C.; Shinde, J.; Soysouvanh, F.; et al. Exome sequencing of hepatocellular carcinomas identifies new mutational signatures and potential therapeutic targets. Nat. Genet. 2015, 47, 505-511. [CrossRef] [PubMed]

113. Sia, D.; Jiao, Y.; Martinez-Quetglas, I.; Kuchuk, O.; Villacorta-Martin, C.; Castro de Moura, M.; Putra, J.; Camprecios, G.; Bassaganyas, L.; Akers, N.; et al. Identification of an Immune-specific Class of Hepatocellular Carcinoma, Based on Molecular Features. Gastroenterology 2017, 153, 812-826. [CrossRef] [PubMed]

114. Harding, J.J.; Nandakumar, S.; Armenia, J.; Khalil, D.N.; Albano, M.; Ly, M.; Shia, J.; Hechtman, J.F.; Kundra, R.; El Dika, I.; et al. Prospective Genotyping of Hepatocellular Carcinoma: Clinical Implications of Next-Generation Sequencing for Matching Patients to Targeted and Immune Therapies. Clin. Cancer Res. Off. J. Am. Assoc. Cancer Res. 2019, 25, 2116-2126. [CrossRef]

115. Ruiz de Galarreta, M.; Bresnahan, E.; Molina-Sánchez, P.; Lindblad, K.E.; Maier, B.; Sia, D.; Puigvehi, M.; Miguela, V.; Casanova-Acebes, M.; Dhainaut, M.; et al. $\beta$-Catenin Activation Promotes Immune Escape and Resistance to Anti-PD-1 Therapy in Hepatocellular Carcinoma. Cancer Discov. 2019, 9, 1124-1141. [CrossRef]

116. Hugo, W.; Zaretsky, J.M.; Sun, L.; Song, C.; Moreno, B.H.; Hu-Lieskovan, S.; Berent-Maoz, B.; Pang, J.; Chmielowski, B.; Cherry, G.; et al. Genomic and Transcriptomic Features of Response to Anti-PD-1 Therapy in Metastatic Melanoma. Cell 2016, 165, 35-44. [CrossRef]

117. Finn, R.S.; Ryoo, B.-Y.; Merle, P.; Kudo, M.; Bouattour, M.; Lim, H.Y.; Breder, V.; Edeline, J.; Chao, Y.; Ogasawara, S.; et al. Pembrolizumab As Second-Line Therapy in Patients With Advanced Hepatocellular Carcinoma in KEYNOTE-240: A Randomized, Double-Blind, Phase III Trial. J. Clin. Oncol. 2020, 38, 193-202. [CrossRef] 
118. Qin, S.; Finn, R.S.; Kudo, M.; Meyer, T.; Vogel, A.; Ducreux, M.; Macarulla, T.M.; Tomasello, G.; Boisserie, F.; Hou, J.; et al. RATIONALE 301 study: Tislelizumab versus sorafenib as first-line treatment for unresectable hepatocellular carcinoma. Future Oncol. 2019, 15, 1811-1822. [CrossRef]

119. Jimenez Exposito, M.J.; Akce, M.; Alvarez, J.L.M.; Assenat, E.; Balart, L.A.; Baron, A.D.; Decaens, T.; Heurgue-Berlot, A.; Martin, A.O.; Paik, S.W.; et al. CA209-9DX: Phase III, randomized, double-blind study of adjuvant nivolumab vs placebo for patients with hepatocellular carcinoma (HCC) at high risk of recurrence after curative resection or ablation. Ann. Oncol. 2018, 29, ix65. [CrossRef]

120. Kaseb, A.O.; Pestana, R.C.; Vence, L.M.; Blando, J.M.; Singh, S.; Ikoma, N.; Vauthey, J.-N.; Allison, J.P.; Sharma, P. Randomized, open-label, perioperative phase II study evaluating nivolumab alone versus nivolumab plus ipilimumab in patients with resectable HCC. J. Clin. Oncol. 2019, 37, 185. [CrossRef]

121. Bang, Y.-J.; Golan, T.; Lin, C.-C.; Dahan, L.; Fu, S.; Moreno, V.; Geva, R.; Reck, M.; Wasserstrom, H.A.; Mi, G.; et al. Ramucirumab (Ram) and durvalumab (Durva) treatment of metastatic non-small cell lung cancer (NSCLC), gastric/gastroesophageal junction (G/GEJ) adenocarcinoma, and hepatocellular carcinoma (HCC) following progression on systemic treatment(s). J. Clin. Oncol. 2019, 37, 2528. [CrossRef]

122. Zhu, A.X.; Finn, R.S.; Ikeda, M.; Sung, M.W.; Baron, A.D.; Kudo, M.; Okusaka, T.; Kobayashi, M.; Kumada, H.; Kaneko, S.; et al. A phase Ib study of lenvatinib (LEN) plus pembrolizumab (PEMBRO) in unresectable hepatocellular carcinoma (uHCC). J. Clin. Oncol. 2020, 38, 4519. [CrossRef]

123. Llovet, J.M.; Kudo, M.; Cheng, A.-L.; Finn, R.S.; Galle, P.R.; Kaneko, S.; Meyer, T.; Qin, S.; Dutcus, C.E.; Chen, E.; et al. Lenvatinib (len) plus pembrolizumab (pembro) for the first-line treatment of patients (pts) with advanced hepatocellular carcinoma (HCC): Phase 3 LEAP-002 study. J. Clin. Oncol. 2019, 37, TPS4152. [CrossRef]

124. Xu, J.; Zhang, Y.; Jia, R.; Yue, C.; Chang, L.; Liu, R.; Zhang, G.; Zhao, C.; Zhang, Y.; Chen, C.; et al. Anti-PD-1 Antibody SHR-1210 Combined with Apatinib for Advanced Hepatocellular Carcinoma, Gastric, or Esophagogastric Junction Cancer: An Open-label, Dose Escalation and Expansion Study. Clin. Cancer Res. Off. J. Am. Assoc. Cancer Res. 2019, 25, 515-523. [CrossRef]

125. Pishvaian, M.J.; Lee, M.S.; Ryoo, B.Y.; Stein, S.; Lee, K.H.; Verret, W.; Spahn, J.; Shao, H.; Liu, B.; Iizuka, K.; et al. Updated safety and clinical activity results from a phase Ib study of atezolizumab + bevacizumab in hepatocellular carcinoma (HCC). Ann. Oncol. 2018, 29, viii718-viii719. [CrossRef]

126. Kudo, M.; Motomura, K.; Wada, Y.; Inaba, Y.; Sakamoto, Y.; Kurosaki, M.; Umeyama, Y.; Kamei, Y.; Yoshimitsu, J.; Fujii, Y.; et al. First-line avelumab + axitinib in patients with advanced hepatocellular carcinoma: Results from a phase $1 b$ trial (VEGF Liver 100). J. Clin. Oncol. 2019, 37, 4072. [CrossRef]

127. Kelley, R.K.; Cheng, A.-L.; Braiteh, F.S.; Park, J.-W.; Benzaghou, F.; Milwee, S.; Borgman, A.; El-Khoueiry, A.B.; Kayali, Z.K.; Zhu, A.X.; et al. Phase 3 (COSMIC-312) study of cabozantinib (C) in combination with atezolizumab (A) versus sorafenib (S) in patients (pts) with advanced hepatocellular carcinoma (aHCC) who have not received previous systemic anticancer therapy. J. Clin. Oncol. 2019, 37, TPS4157. [CrossRef]

128. Knox, J.; Cheng, A.; Cleary, S.; Galle, P.; Kokudo, N.; Lencioni, R.; Park, J.; Zhou, J.; Mann, H.; Morgan, S.; et al. A phase 3 study of durvalumab with or without bevacizumab as adjuvant therapy in patients with hepatocellular carcinoma (HCC) who are at high risk of recurrence after curative hepatic resection. Ann. Oncol. 2019, 30. [CrossRef]

129. Sangro, B.; Kudo, M.; Qin, S.; Ren, Z.; Chan, S.; Erinjeri, J.; Arai, Y.; He, P.; Morgan, S.; Cohen, G.; et al. P-347 A phase 3, randomized, double-blind, placebo-controlled study of transarterial chemoembolization combined with durvalumab or durvalumab plus bevacizumab therapy in patients with locoregional hepatocellular carcinoma: EMERALD-1. Ann. Oncol. 2020, 31, S202-S203. [CrossRef]

130. Floudas, C.S.; Xie, C.; Brar, G.; Morelli, M.P.; Fioravanti, S.; Walker, M.; Mabry-Hrones, D.; Wood, B.J.; Levy, E.B.; Krishnasamy, V.P.; et al. Combined immune checkpoint inhibition (ICI) with tremelimumab and durvalumab in patients with advanced hepatocellular carcinoma (HCC) or biliary tract carcinomas (BTC). J. Clin. Oncol. 2019, 37, 336. [CrossRef]

131. Popovic, A.; Sugar, E.; Ferguson, A.; Wilt, B.; Durham, J.N.; Kamel, I.R.; Kim, A.; Philosophe, B.; Anders, R.A.; Jaffee, E.M.; et al. Abstract CT207: Feasibility of neoadjuvant cabozantinib plus nivolumab followed by definitive resection for patients with locally advanced hepatocellular carcinoma: A Phase Ib trial (NCT03299946). Cancer Res. 2019, 79, CT207. [CrossRef] 
132. Motzer, R.J.; Tannir, N.M.; McDermott, D.F.; Aren Frontera, O.; Melichar, B.; Choueiri, T.K.; Plimack, E.R.; Barthelemy, P.; Porta, C.; George, S.; et al. Nivolumab plus Ipilimumab versus Sunitinib in Advanced Renal-Cell Carcinoma. N. Engl. J. Med. 2018, 378, 1277-1290. [CrossRef] [PubMed]

133. Wolchok, J.D.; Chiarion-Sileni, V.; Gonzalez, R.; Rutkowski, P.; Grob, J.J.; Cowey, C.L.; Lao, C.D.; Wagstaff, J.; Schadendorf, D.; Ferrucci, P.F.; et al. Overall Survival with Combined Nivolumab and Ipilimumab in Advanced Melanoma. N. Engl. J. Med. 2017, 377, 1345-1356. [CrossRef] [PubMed]

134. Hellmann, M.D.; Paz-Ares, L.; Bernabe Caro, R.; Zurawski, B.; Kim, S.W.; Carcereny Costa, E.; Park, K.; Alexandru, A.; Lupinacci, L.; de la Mora Jimenez, E.; et al. Nivolumab plus Ipilimumab in Advanced Non-Small-Cell Lung Cancer. N. Engl. J. Med. 2019, 381, 2020-2031. [CrossRef]

135. Kaseb, A.; Vence, L.; Blando, J.; Yadav, S.; Ikoma, N.; Pestana, R.; Vauthey, J.; Cao, H.; Chun, Y.; Sakamura, D.; et al. Randomized, open-label, perioperative phase II study evaluating nivolumab alone versus nivolumab plus ipilimumab in patients with resectable HCC. Ann. Oncol. Off. J. Eur. Soc. Med. Oncol. 2019, 30 (Suppl. 4), iv112. [CrossRef]

136. Kelley, R.K.; Abou-Alfa, G.K.; Bendell, J.C.; Kim, T.-Y.; Borad, M.J.; Yong, W.-P.; Morse, M.; Kang, Y.-K.; Rebelatto, M.; Makowsky, M.; et al. Phase I/II study of durvalumab and tremelimumab in patients with unresectable hepatocellular carcinoma (HCC): Phase I safety and efficacy analyses. J. Clin. Oncol. 2017, 35, 4073. [CrossRef]

137. Deng, Y.R.; Liu, W.B.; Lian, Z.X.; Li, X.; Hou, X. Sorafenib inhibits macrophage-mediated epithelial-mesenchymal transition in hepatocellular carcinoma. Oncotarget 2016, 7, 38292-38305. [CrossRef]

138. Kato, Y.; Tabata, K.; Kimura, T.; Yachie-Kinoshita, A.; Ozawa, Y.; Yamada, K.; Ito, J.; Tachino, S.; Hori, Y.; Matsuki, M.; et al. Lenvatinib plus anti-PD-1 antibody combination treatment activates CD8+ T cells through reduction of tumor-associated macrophage and activation of the interferon pathway. PLoS ONE 2019, 14, e0212513. [CrossRef]

139. Zerbini, A.; Pilli, M.; Laccabue, D.; Pelosi, G.; Molinari, A.; Negri, E.; Cerioni, S.; Fagnoni, F.; Soliani, P.; Ferrari, C.; et al. Radiofrequency thermal ablation for hepatocellular carcinoma stimulates autologous NK-cell response. Gastroenterology 2010, 138, 1931-1942. [CrossRef]

140. Nobuoka, D.; Motomura, Y.; Shirakawa, H.; Yoshikawa, T.; Kuronuma, T.; Takahashi, M.; Nakachi, K.; Ishii, H.; Furuse, J.; Gotohda, N.; et al. Radiofrequency ablation for hepatocellular carcinoma induces glypican-3 peptide-specific cytotoxic T lymphocytes. Int. J. Oncol. 2012, 40, 63-70. [CrossRef]

141. Hansler, J.; Wissniowski, T.T.; Schuppan, D.; Witte, A.; Bernatik, T.; Hahn, E.G.; Strobel, D. Activation and dramatically increased cytolytic activity of tumor specific $\mathrm{T}$ lymphocytes after radio-frequency ablation in patients with hepatocellular carcinoma and colorectal liver metastases. World J. Gastroenterol. 2006, 12, 3716-3721. [CrossRef] [PubMed]

142. den Brok, M.H.; Sutmuller, R.P.; van der Voort, R.; Bennink, E.J.; Figdor, C.G.; Ruers, T.J.; Adema, G.J. In situ tumor ablation creates an antigen source for the generation of antitumor immunity. Cancer Res. 2004, 64, 4024-4029. [CrossRef] [PubMed]

143. Den Brok, M.H.; Sutmuller, R.P.; Nierkens, S.; Bennink, E.J.; Frielink, C.; Toonen, L.W.; Boerman, O.C.; Figdor, C.G.; Ruers, T.J.; Adema, G.J. Efficient loading of dendritic cells following cryo and radiofrequency ablation in combination with immune modulation induces anti-tumour immunity. Br. J. Cancer 2006, 95, 896-905. [CrossRef] [PubMed]

144. Greten, T.F.; Mauda-Havakuk, M.; Heinrich, B.; Korangy, F.; Wood, B.J. Combined locoregionalimmunotherapy for liver cancer. J. Hepatol. 2019, 70, 999-1007. [CrossRef] [PubMed]

145. Apetoh, L.; Mignot, G.; Panaretakis, T.; Kroemer, G.; Zitvogel, L. Immunogenicity of anthracyclines: Moving towards more personalized medicine. Trends Mol. Med. 2008, 14, 141-151. [CrossRef]

146. Hoechst, B.; Ormandy, L.A.; Ballmaier, M.; Lehner, F.; Kruger, C.; Manns, M.P.; Greten, T.F.; Korangy, F. A new population of myeloid-derived suppressor cells in hepatocellular carcinoma patients induces CD4(+)CD25(+)Foxp3(+) T cells. Gastroenterology 2008, 135, 234-243. [CrossRef]

147. Arihara, F.; Mizukoshi, E.; Kitahara, M.; Takata, Y.; Arai, K.; Yamashita, T.; Nakamoto, Y.; Kaneko, S. Increase in CD14+HLA-DR -/low myeloid-derived suppressor cells in hepatocellular carcinoma patients and its impact on prognosis. Cancer Immunol. Immunother. 2013, 62, 1421-1430. [CrossRef]

148. Chew, V.; Lee, Y.H.; Pan, L.; Nasir, N.J.M.; Lim, C.J.; Chua, C.; Lai, L.; Hazirah, S.N.; Lim, T.K.H.; Goh, B.K.P.; et al. Immune activation underlies a sustained clinical response to Yttrium-90 radioembolisation in hepatocellular carcinoma. Gut 2019, 68, 335-346. [CrossRef] 
149. Bresnahan, E.; Lindblad, K.E.; Ruiz de Galarreta, M.; Lujambio, A. Mouse models of oncoimmunology in hepatocellular carcinoma. Clin. Cancer Res. Off. J. Am. Assoc. Cancer Res. 2020. [CrossRef]

150. Olson, B.; Li, Y.; Lin, Y.; Liu, E.T.; Patnaik, A. Mouse Models for Cancer Immunotherapy Research. Cancer Discov. 2018, 8, 1358-1365. [CrossRef]

151. Wolchok, J.D. PD-1 Blockers. Cell 2015, 162, 937. [CrossRef] [PubMed]

152. El Dika, I.; Khalil, D.N.; Abou-Alfa, G.K. Immune checkpoint inhibitors for hepatocellular carcinoma. Cancer 2019, 125, 3312-3319. [CrossRef]

153. Brown, Z.J.; Yu, S.J.; Heinrich, B.; Ma, C.; Fu, Q.; Sandhu, M.; Agdashian, D.; Zhang, Q.; Korangy, F.; Greten, T.F. Indoleamine 2,3-dioxygenase provides adaptive resistance to immune checkpoint inhibitors in hepatocellular carcinoma. Cancer Immunol. Immunother. 2018, 67, 1305-1315. [CrossRef] [PubMed]

154. Kimura, T.; Kato, Y.; Ozawa, Y.; Kodama, K.; Ito, J.; Ichikawa, K.; Yamada, K.; Hori, Y.; Tabata, K.; Takase, K.; et al. Immunomodulatory activity of lenvatinib contributes to antitumor activity in the Hepa1-6 hepatocellular carcinoma model. Cancer Sci. 2018, 109, 3993-4002. [CrossRef] [PubMed]

155. Lee, J.; Liao, R.; Wang, G.; Yang, B.H.; Luo, X.; Varki, N.M.; Qiu, S.J.; Ren, B.; Fu, W.; Feng, G.S. Preventive Inhibition of Liver Tumorigenesis by Systemic Activation of Innate Immune Functions. Cell Rep. 2017, 21, 1870-1882. [CrossRef] [PubMed]

156. Wen, L.; Xin, B.; Wu, P.; Lin, C.H.; Peng, C.; Wang, G.; Lee, J.; Lu, L.F.; Feng, G.S. An Efficient Combination Immunotherapy for Primary Liver Cancer by Harmonized Activation of Innate and Adaptive Immunity in Mice. Hepatology 2019, 69, 2518-2532. [CrossRef] [PubMed]

157. Zhu, Y.; Yang, J.; Xu, D.; Gao, X.M.; Zhang, Z.; Hsu, J.L.; Li, C.W.; Lim, S.O.; Sheng, Y.Y.; Zhang, Y.; et al. Disruption of tumour-associated macrophage trafficking by the osteopontin-induced colony-stimulating factor-1 signalling sensitises hepatocellular carcinoma to anti-PD-L1 blockade. Gut 2019, 68, 1653-1666. [CrossRef]

158. Llopiz, D.; Ruiz, M.; Villanueva, L.; Iglesias, T.; Silva, L.; Egea, J.; Lasarte, J.J.; Pivette, P.; Trochon-Joseph, V.; Vasseur, B.; et al. Enhanced anti-tumor efficacy of checkpoint inhibitors in combination with the histone deacetylase inhibitor Belinostat in a murine hepatocellular carcinoma model. Cancer Immunol. Immunother. 2019, 68, 379-393. [CrossRef]

159. Xiang, J.; Zhang, N.; Sun, H.; Su, L.; Zhang, C.; Xu, H.; Feng, J.; Wang, M.; Chen, J.; Liu, L.; et al. Disruption of SIRT7 Increases the Efficacy of Checkpoint Inhibitor via MEF2D Regulation of Programmed Cell Death 1 Ligand 1 in Hepatocellular Carcinoma Cells. Gastroenterology 2020, 158, 664-678.e24. [CrossRef]

160. Kaufman, H.L.; Kohlhapp, F.J.; Zloza, A. Oncolytic viruses: A new class of immunotherapy drugs. Nat. Rev. Drug Discov. 2015, 14, 642-662. [CrossRef]

161. Yoo, S.Y.; Badrinath, N.; Woo, H.Y.; Heo, J. Oncolytic Virus-Based Immunotherapies for Hepatocellular Carcinoma. Mediat. Inflamm. 2017, 2017. [CrossRef] [PubMed]

162. Heo, J.; Reid, T.; Ruo, L.; Breitbach, C.J.; Rose, S.; Bloomston, M.; Cho, M.; Lim, H.Y.; Chung, H.C.; Kim, C.W.; et al. Randomized dose-finding clinical trial of oncolytic immunotherapeutic vaccinia JX-594 in liver cancer. Nat. Med. 2013, 19, 329-336. [CrossRef] [PubMed]

163. Nakatake, R.; Kaibori, M.; Nakamura, Y.; Tanaka, Y.; Matushima, H.; Okumura, T.; Murakami, T.; Ino, Y.; Todo, T.; Kon, M. Third-generation oncolytic herpes simplex virus inhibits the growth of liver tumors in mice. Cancer Sci. 2018, 109, 600-610. [CrossRef] [PubMed]

164. Fukuhara, H.; Ino, Y.; Todo, T. Oncolytic virus therapy: A new era of cancer treatment at dawn. Cancer Sci. 2016, 107, 1373-1379. [CrossRef]

165. Luo, Y.; Lin, C.; Ren, W.; Ju, F.; Xu, Z.; Liu, H.; Yu, Z.; Chen, J.; Zhang, J.; Liu, P.; et al. Intravenous Injections of a Rationally Selected Oncolytic Herpes Virus as a Potent Virotherapy for Hepatocellular Carcinoma. Mol. Ther. Oncolytics 2019, 15, 153-165. [CrossRef]

166. Maeng, H.; Terabe, M.; Berzofsky, J.A. Cancer vaccines: Translation from mice to human clinical trials. Curr. Opin. Immunol. 2018, 51, 111-122. [CrossRef]

167. Si, C.; Xu, M.; Lu, M.; Yu, Y.; Yang, M.; Yan, M.; Zhou, L.; Yang, X. In vivo antitumor activity evaluation of cancer vaccines prepared by various antigen forms in a murine hepatocellular carcinoma model. Oncol. Lett. 2017, 14, 7391-7397. [CrossRef]

168. Huang, F.; Chen, J.; Lan, R.; Wang, Z.; Chen, R.; Lin, J.; Zhang, L.; Fu, L. delta-Catenin peptide vaccines repress hepatocellular carcinoma growth via CD8(+) T cell activation. Oncoimmunology 2018, 7, e1450713. [CrossRef] 
169. Wu, Q.; Pi, L.; Le Trinh, T.; Zuo, C.; Xia, M.; Jiao, Y.; Hou, Z.; Jo, S.; Puszyk, W.; Pham, K.; et al. A Novel Vaccine Targeting Glypican-3 as a Treatment for Hepatocellular Carcinoma. Mol. Ther. J. Am. Soc. Gene Ther. 2017, 25, 2299-2308. [CrossRef]

170. Hanke, P.; Serwe, M.; Dombrowski, F.; Sauerbruch, T.; Caselmann, W.H. DNA vaccination with AFP-encoding plasmid DNA prevents growth of subcutaneous AFP-expressing tumors and does not interfere with liver regeneration in mice. Cancer Gene Ther. 2002, 9, 346-355. [CrossRef]

171. Tian, G.; Yi, J.L.; Xiong, P. Specific cellular immunity and antitumor responses in C57BL/6 mice induced by DNA vaccine encoding murine AFP. Hepatobiliary Pancreat. Dis. Int. 2004, 3, 440-443. [PubMed]

172. Tan, X.H.; Zhu, Q.; Liu, C.; Liu, X.L.; Shao, X.T.; Wei, B. Immunization with dendritic cells infected with human AFP adenovirus vector effectively elicits immunity against mouse hepatocellular carcinomas. Zhonghua Zhong Liu Za Zhi 2006, 28, 13-16. [PubMed]

173. Lan, Y.H.; Li, Y.G.; Liang, Z.W.; Chen, M.; Peng, M.L.; Tang, L.; Hu, H.D.; Ren, H. A DNA vaccine against chimeric AFP enhanced by HSP70 suppresses growth of hepatocellular carcinoma. Cancer Immunol. Immunother. 2007, 56, 1009-1016. [CrossRef] [PubMed]

174. Hong, Y.; Peng, Y.; Guo, Z.S.; Guevara-Patino, J.; Pang, J.; Butterfield, L.H.; Mivechi, N.F.; Munn, D.H.; Bartlett, D.L.; He, Y. Epitope-optimized alpha-fetoprotein genetic vaccines prevent carcinogen-induced murine autochthonous hepatocellular carcinoma. Hepatology 2014, 59, 1448-1458. [CrossRef]

175. Ahn, H.M.; Ryu, J.; Song, J.M.; Lee, Y.; Kim, H.J.; Ko, D.; Choi, I.; Kim, S.J.; Lee, J.W.; Kim, S. Anti-cancer Activity of Novel TM4SF5-Targeting Antibodies through TM4SF5 Neutralization and Immune Cell-Mediated Cytotoxicity. Theranostics 2017, 7, 594-613. [CrossRef]

176. Piotrowska, D.; Baczynska, K. Incidence of positive Waaler-Rose test in women exposed to urogenital infections. Reumatologia 1978, 16, 21-24.

177. Feng, M.; Gao, W.; Wang, R.; Chen, W.; Man, Y.G.; Figg, W.D.; Wang, X.W.; Dimitrov, D.S.; Ho, M. Therapeutically targeting glypican-3 via a conformation-specific single-domain antibody in hepatocellular carcinoma. Proc. Natl. Acad. Sci. USA 2013, 110, E1083-E1091. [CrossRef]

178. Jin, Z.; Lei, L.; Lin, D.; Liu, Y.; Song, Y.; Gong, H.; Zhu, Y.; Mei, Y.; Hu, B.; Wu, Y.; et al. IL-33 Released in the Liver Inhibits Tumor Growth via Promotion of CD4(+) and CD8(+) T Cell Responses in Hepatocellular Carcinoma. J. Immunol. 2018, 201, 3770-3779. [CrossRef]

179. Zhuang, L.; Fulton, R.J.; Rettman, P.; Sayan, A.E.; Coad, J.; Al-Shamkhani, A.; Khakoo, S.I. Activity of IL-12/15/18 primed natural killer cells against hepatocellular carcinoma. Hepatol. Int. 2019, 13, 75-83. [CrossRef]

180. Subleski, J.J.; Hall, V.L.; Back, T.C.; Ortaldo, J.R.; Wiltrout, R.H. Enhanced antitumor response by divergent modulation of natural killer and natural killer T cells in the liver. Cancer Res. 2006, 66, 11005-11012. [CrossRef]

181. Zhang, R.; Zhang, Z.; Liu, Z.; Wei, D.; Wu, X.; Bian, H.; Chen, Z. Adoptive cell transfer therapy for hepatocellular carcinoma. Front. Med. 2019, 13, 3-11. [CrossRef] [PubMed]

182. Dargel, C.; Bassani-Sternberg, M.; Hasreiter, J.; Zani, F.; Bockmann, J.H.; Thiele, F.; Bohne, F.; Wisskirchen, K.; Wilde, S.; Sprinzl, M.F.; et al. T Cells Engineered to Express a T-Cell Receptor Specific for Glypican-3 to Recognize and Kill Hepatoma Cells In Vitro and in Mice. Gastroenterology 2015, 149, 1042-1052. [CrossRef] [PubMed]

183. Gao, H.; Li, K.; Tu, H.; Pan, X.; Jiang, H.; Shi, B.; Kong, J.; Wang, H.; Yang, S.; Gu, J.; et al. Development of T cells redirected to glypican-3 for the treatment of hepatocellular carcinoma. Clin. Cancer Res. Off. J. Am. Assoc. Cancer Res. 2014, 20, 6418-6428. [CrossRef] [PubMed]

184. Yu, M.; Luo, H.; Fan, M.; Wu, X.; Shi, B.; Di, S.; Liu, Y.; Pan, Z.; Jiang, H.; Li, Z. Development of GPC3-Specific Chimeric Antigen Receptor-Engineered Natural Killer Cells for the Treatment of Hepatocellular Carcinoma. Mol. Ther. 2018, 26, 366-378. [CrossRef]

185. Jiang, Z.; Jiang, X.; Chen, S.; Lai, Y.; Wei, X.; Li, B.; Lin, S.; Wang, S.; Wu, Q.; Liang, Q.; et al. Anti-GPC3-CAR T Cells Suppress the Growth of Tumor Cells in Patient-Derived Xenografts of Hepatocellular Carcinoma. Front. Immunol. 2016, 7, 690. [CrossRef]

186. Wu, X.; Luo, H.; Shi, B.; Di, S.; Sun, R.; Su, J.; Liu, Y.; Li, H.; Jiang, H.; Li, Z. Combined Antitumor Effects of Sorafenib and GPC3-CAR T Cells in Mouse Models of Hepatocellular Carcinoma. Mol. Ther. 2019, 27, 1483-1494. [CrossRef] 
187. Liu, M.; Zhou, J.; Liu, X.; Feng, Y.; Yang, W.; Wu, F.; Cheung, O.K.; Sun, H.; Zeng, X.; Tang, W.; et al. Targeting monocyte-intrinsic enhancer reprogramming improves immunotherapy efficacy in hepatocellular carcinoma. Gut 2020, 69, 365-379. [CrossRef]

188. Zhou, J.; Liu, M.; Sun, H.; Feng, Y.; Xu, L.; Chan, A.W.H.; Tong, J.H.; Wong, J.; Chong, C.C.N.; Lai, P.B.S.; et al. Hepatoma-intrinsic CCRK inhibition diminishes myeloid-derived suppressor cell immunosuppression and enhances immune-checkpoint blockade efficacy. Gut 2018, 67, 931-944. [CrossRef]

189. Mantovani, A.; Marchesi, F.; Malesci, A.; Laghi, L.; Allavena, P. Tumour-associated macrophages as treatment targets in oncology. Nat. Reviews. Clin. Oncol. 2017, 14, 399-416. [CrossRef]

190. Degroote, H.; Van Dierendonck, A.; Geerts, A.; Van Vlierberghe, H.; Devisscher, L. Preclinical and Clinical Therapeutic Strategies Affecting Tumor-Associated Macrophages in Hepatocellular Carcinoma. J. Immunol. Res. 2018, 2018. [CrossRef]

191. Zheng, X.; Turkowski, K.; Mora, J.; Brüne, B.; Seeger, W.; Weigert, A.; Savai, R. Redirecting tumor-associated macrophages to become tumoricidal effectors as a novel strategy for cancer therapy. Oncotarget 2017, 8, 48436-48452. [CrossRef] [PubMed]

192. Ao, J.Y.; Zhu, X.D.; Chai, Z.T.; Cai, H.; Zhang, Y.Y.; Zhang, K.Z.; Kong, L.Q.; Zhang, N.; Ye, B.G.; Ma, D.N.; et al. Colony-Stimulating Factor 1 Receptor Blockade Inhibits Tumor Growth by Altering the Polarization of Tumor-Associated Macrophages in Hepatocellular Carcinoma. Mol. Cancer Ther. 2017, 16, 1544-1554. [CrossRef] [PubMed]

193. Li, X.; Yao, W.; Yuan, Y.; Chen, P.; Li, B.; Li, J.; Chu, R.; Song, H.; Xie, D.; Jiang, X.; et al. Targeting of tumour-infiltrating macrophages via CCL2/CCR2 signalling as a therapeutic strategy against hepatocellular carcinoma. Gut 2017, 66, 157-167. [CrossRef] [PubMed]

194. Yao, W.; Ba, Q.; Li, X.; Li, H.; Zhang, S.; Yuan, Y.; Wang, F.; Duan, X.; Li, J.; Zhang, W.; et al. A Natural CCR2 Antagonist Relieves Tumor-associated Macrophage-mediated Immunosuppression to Produce a Therapeutic Effect for Liver Cancer. EBioMedicine 2017, 22, 58-67. [CrossRef] [PubMed]

195. Chai, Z.T.; Zhu, X.D.; Ao, J.Y.; Wang, W.Q.; Gao, D.M.; Kong, J.; Zhang, N.; Zhang, Y.Y.; Ye, B.G.; Ma, D.N.; et al. microRNA-26a suppresses recruitment of macrophages by down-regulating macrophage colony-stimulating factor expression through the PI3K/Akt pathway in hepatocellular carcinoma. J. Hematol. Oncol. 2015, 8, 56. [CrossRef]

196. Tan, H.Y.; Wang, N.; Man, K.; Tsao, S.W.; Che, C.M.; Feng, Y. Autophagy-induced RelB/p52 activation mediates tumour-associated macrophage repolarisation and suppression of hepatocellular carcinoma by natural compound baicalin. Cell Death Dis. 2015, 6, e1942. [CrossRef]

197. Liu, P.; Chen, L.; Zhang, H. Natural Killer Cells in Liver Disease and Hepatocellular Carcinoma and the NK Cell-Based Immunotherapy. J. Immunol. Res. 2018, 2018, 1206737. [CrossRef]

198. Mikulak, J.; Bruni, E.; Oriolo, F.; Di Vito, C.; Mavilio, D. Hepatic Natural Killer Cells: Organ-Specific Sentinels of Liver Immune Homeostasis and Physiopathology. Front. Immunol. 2019, 10, 946. [CrossRef]

199. Juengpanich, S.; Shi, L.; Iranmanesh, Y.; Chen, J.; Cheng, Z.; Khoo, A.K.; Pan, L.; Wang, Y.; Cai, X. The role of natural killer cells in hepatocellular carcinoma development and treatment: A narrative review. Transl. Oncol. 2019, 12, 1092-1107. [CrossRef]

200. Hoechst, B.; Voigtlaender, T.; Ormandy, L.; Gamrekelashvili, J.; Zhao, F.; Wedemeyer, H.; Lehner, F.; Manns, M.P.; Greten, T.F.; Korangy, F. Myeloid derived suppressor cells inhibit natural killer cells in patients with hepatocellular carcinoma via the NKp30 receptor. Hepatology 2009, 50, 799-807. [CrossRef]

201. Liu, C.; Yu, S.; Kappes, J.; Wang, J.; Grizzle, W.E.; Zinn, K.R.; Zhang, H.G. Expansion of spleen myeloid suppressor cells represses NK cell cytotoxicity in tumor-bearing host. Blood 2007, 109, 4336-4342. [CrossRef] [PubMed]

(C) 2020 by the authors. Licensee MDPI, Basel, Switzerland. This article is an open access article distributed under the terms and conditions of the Creative Commons Attribution (CC BY) license (http://creativecommons.org/licenses/by/4.0/). 